US Army Corps of Engineers ${ }_{\circledast}$

Engineer Research and

Development Center

\title{
Application of a Radiation-Derived Temperature Index Model to the Willow Creek Watershed in Idaho, USA
}

Daniel Hamill, Jeremy Giovando, Chandler Engel, Travis Dahl, and July 2021 Mike Bartles

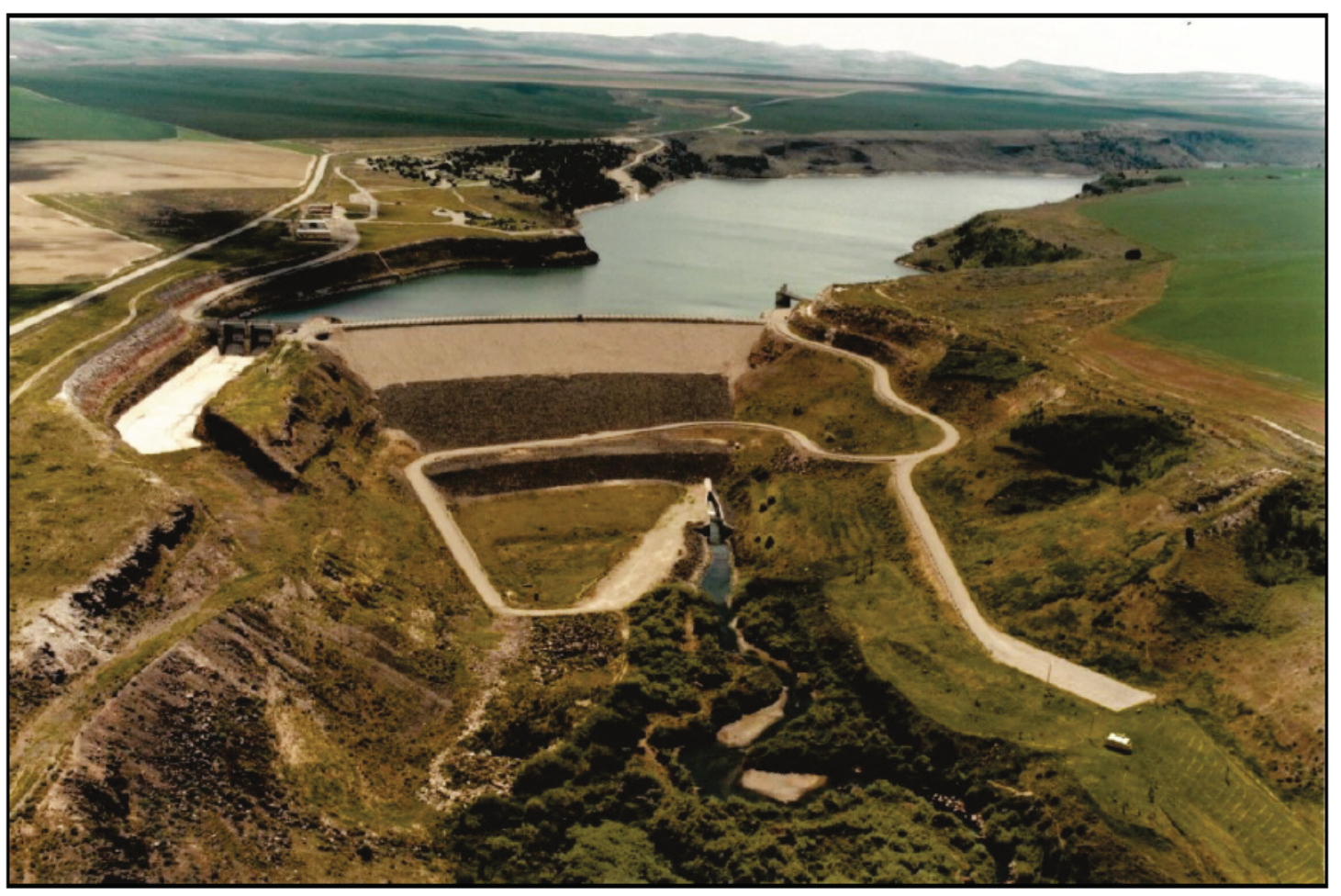


The US Army Engineer Research and Development Center (ERDC) solves the nation's toughest engineering and environmental challenges. ERDC develops innovative solutions in civil and military engineering, geospatial sciences, water resources, and environmental sciences for the Army, the Department of Defense, civilian agencies, and our nation's public good. Find out more at www.erdc.usace.army.mil.

To search for other technical reports published by ERDC, visit the ERDC online library at https://erdclibrary.on.worldcat.org/discovery. 


\title{
Application of a Radiation-Derived Temperature Index Model to the Willow Creek Watershed in Idaho, USA
}

\author{
Daniel Hamill, Jeremy Giovando, and Chandler Engel \\ Cold Regions Research and Engineering Laboratory \\ US Army Engineer Research and Development Center \\ 72 Lyme Road \\ Hanover, NH 03755 \\ Travis Dahl \\ Coastal and Hydraulics Laboratory \\ US Army Engineer Research and Development Center \\ 3909 Halls Ferry Road \\ Vicksburg, MS 39180-6199 \\ Mike Bartles \\ Hydrologic Engineering Center \\ 609 Second Street \\ Davis, CA 95616-4687
}

Final report

Approved for public release; distribution is unlimited.

\author{
Prepared for Flood and Coastal System (FCS) Research and Development Program \\ 3909 Halls Ferry Road \\ Vicksburg, MS 39180 \\ Under Funding Account Code U4368971, AMSCO Code 31398
}




\section{Abstract}

The ability to simulate snow accumulation and melting processes is fundamental to developing real-time hydrological models in watersheds with a snowmelt-dominated flow regime. A primary source of uncertainty with this model development approach is the subjectivity related to which historical periods to use and how to combine parameters from multiple calibration events. The Hydrologic Engineering Center, Hydrological Modeling System, has recently implemented a hybrid temperature index (TI) snow module that has not been extensively tested. This study evaluates a radiatative temperature index (RTI) model's performance relative to the traditional air TI model. The TI model for Willow Creek performed reasonably well in both the calibration and validation years. The results of the RTI calibration and validation simulations resulted in additional questions related to how best to parameterize this snow model. An RTI parameter sensitivity analysis indicates that the choice of calibration years will have a substantial impact on the parameters and thus the streamflow results. Based on the analysis completed in this study, further refinement and verification of the RTI model calculations are required before an objective comparison with the TI model can be completed.

DISCLAIMER: The contents of this report are not to be used for advertising, publication, or promotional purposes. Citation of trade names does not constitute an official endorsement or approval of the use of such commercial products. All product names and trademarks cited are the property of their respective owners. The findings of this report are not to be construed as an official Department of the Army position unless so designated by other authorized documents. 


\section{Contents}

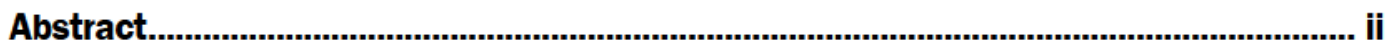

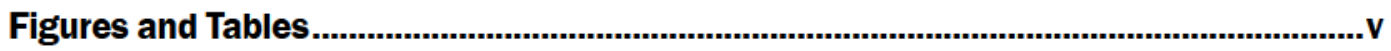

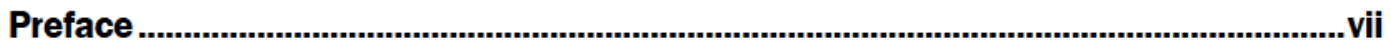

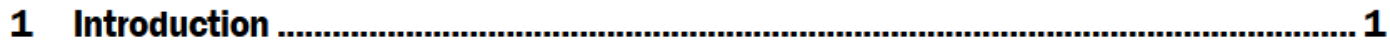

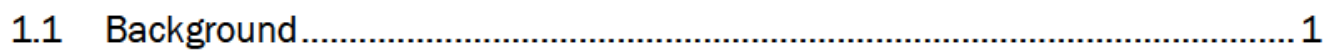

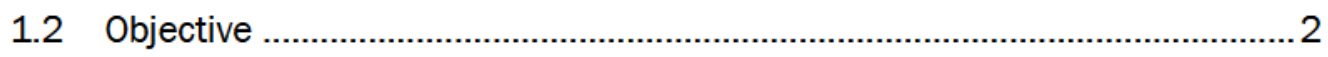

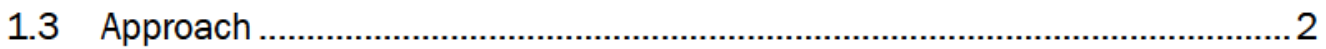

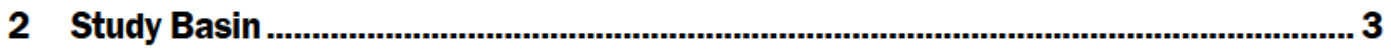

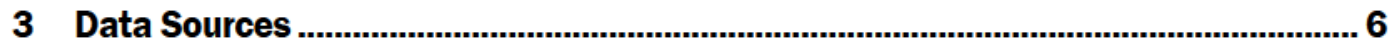

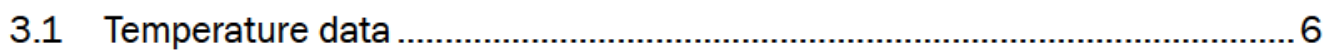

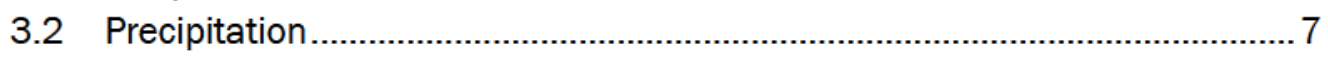

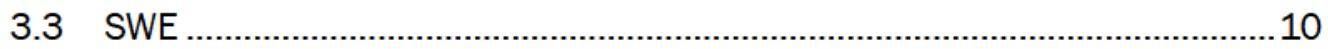

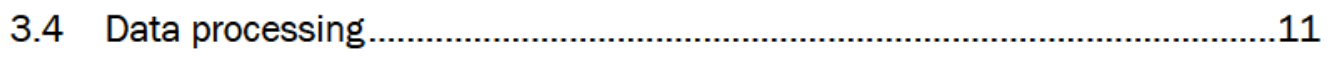

4 Hydrological Modeling System (HMS) Model Modifications..................................13

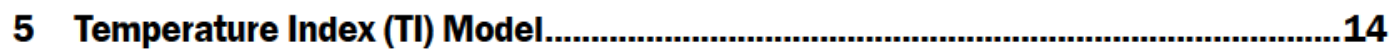

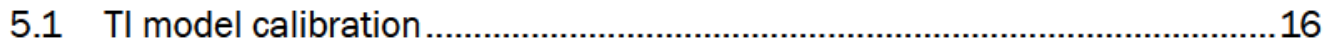

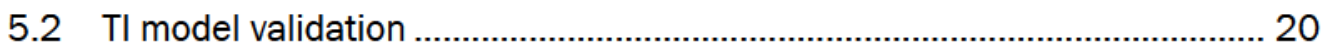

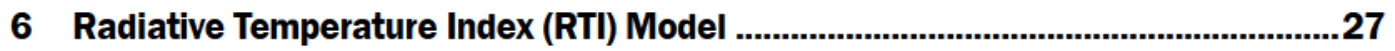

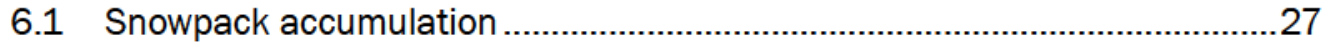

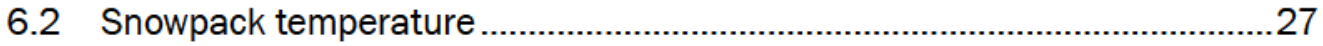

6.3 Surface melt ............................................................................... 28

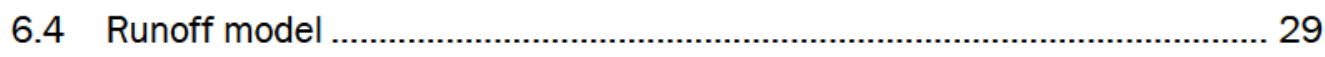

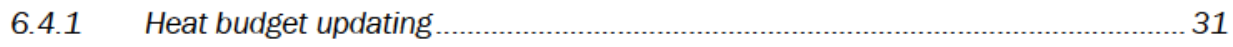

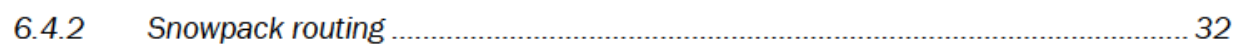

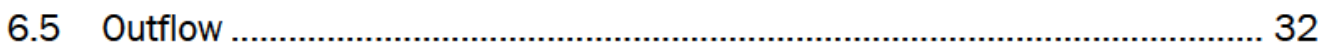

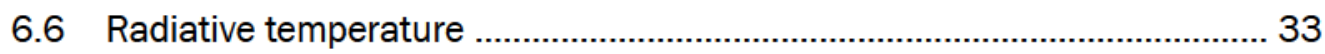

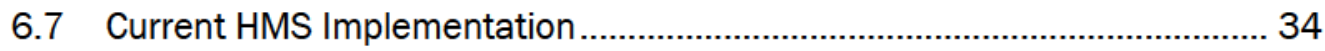

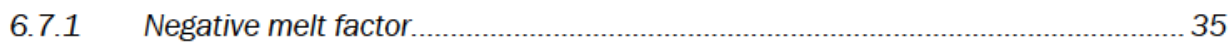

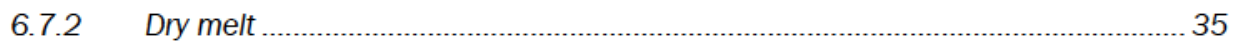

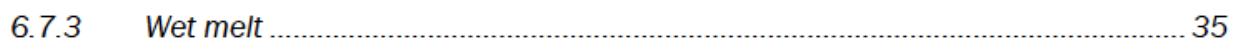

6.7.4 Downwelling long wave radiation.......................................................................... 36

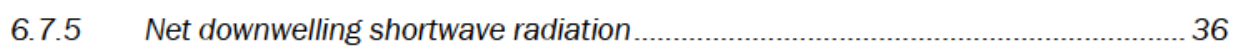

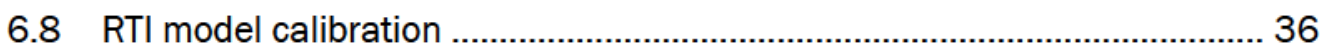

6.9 RTI model validation ........................................................................... 39

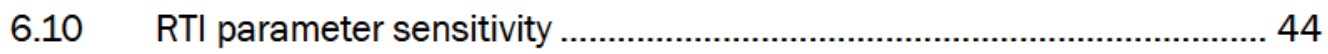

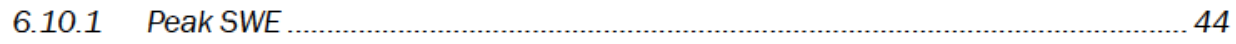


6.10.2 Peak SWE timing ....................................................................................... 45

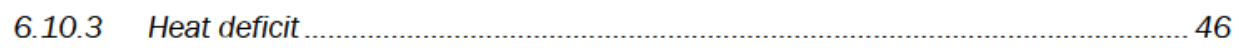

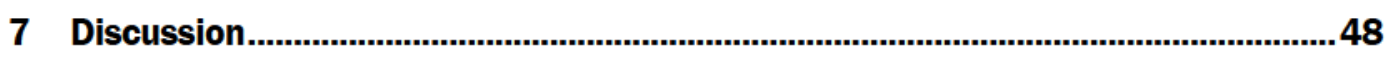

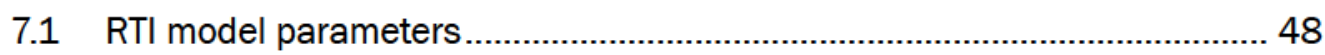

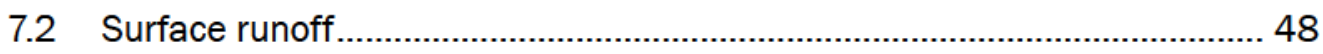

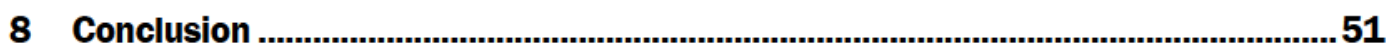

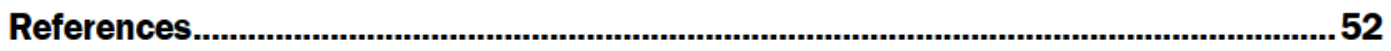

Acronyms and Abbreviations ................................................................................54

Report Documentation Page 


\section{Figures and Tables}

\section{Figures}

Figure 1. Willow Creek subbasin delineation and location map.. 3

Figure 2. Subbasin hypsometric curves for Willow Creek calculated from the National Elevation Dataset (Gesch et al. 2018). 4

Figure 3. NLCD 2016 land classifications for Willow Creek watershed.

Figure 4. Hourly average RTMA air temperature time series for Willow Creek watershed.

Figure 5. Cumulative precipitation curves for WYs 2015-2020 averaged over the Willow Creek watershed.

Figure 6. Subbasin averaged cumulative precipitation for WY 2016.

Figure 7. Cumulative precipitation depth maps showing the gauge correction artifacts in the MRMS gauge corrected QPE grids in Willow Creek. The blue areas indicate anomalously high precipitation.

Figure 8 . Normalized MRMS subbasin averaged cumulative precipitation depths for WY 2016.

Figure 9. UA SWE subbasin averaged time series.

Figure 10. HMS basin model for Willow Creek.

Figure 11. TI flow chart for converting surface melt and liquid precipitation to liquid water at the soil surface.

Figure 12. TI snowmelt calibration results for the WY 2016 ........................................ 18

Figure 13. TI snowmelt calibration results for the WY 2017. ........................................... 19

Figure 14. TI model simulation SWE time series for the WY 2018.................................... 21

Figure 15. TI model simulation SWE time series for the WY 2019.................................. 23

Figure 16. TI model simulation SWE time series for the WY 2020.................................. 25

Figure 17. Flow chart summarizing the RTI runoff model................................................30

Figure 18. RTI snowmelt calibration for the WY 2016................................................... 37

Figure 19. RTI snowmelt calibration for the WY 2017.....................................................38

Figure 20. RTI simulated SWE time series for the WY 2018...........................................39

Figure 21. RTI simulated SWE time series for the WY 2019........................................... 41

Figure 22. RTI simulated SWE time series for the WY 2020............................................. 42

Figure 23. ATI parameter relationship between modeled peak SWE....................................4 44

Figure 24. Relationship between maximum negative melt factor, ATI coefficient, and peak SWE.

Figure 25. Relationship between maximum negative melt factor, ATI coefficient, and peak SWE timing.

Figure 26. Influence of maximum negative melt factor and ATI coefficient on the heat deficit budget.

Figure 27. Willow Creek below Tex (13057940) streamflow for the WY 2016.................. 49

Figure 28. Willow Creek below Tex streamflow for the WY 2017. 


\section{Tables}

Table 1. HMS model geographic information system (GIS) metadata................................ 11

Table 2. TI snowmelt calibration parameters for the WY 2016 ....................................... 17

Table 3. TI snowmelt calibration parameters for the WY 2017. ................................... 17

Table 4. TI snowmelt calibration statistics for WYs 2016 and 2017.................................... 20

Table 5. Average calibration parameters for TI model (average of 2016 and

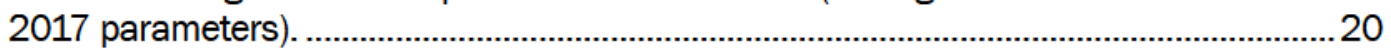

Table 6. TI model simulation statistics for WY 2018

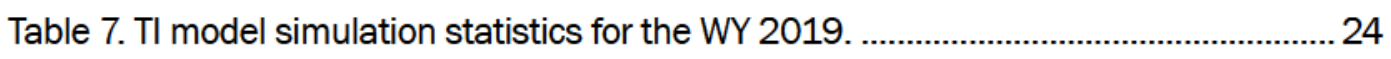

Table 8. TI simulation statistics for the WY 2020............................................................. 26

Table 9. RTI model runoff parameter descriptions for variables in Figure 18.....................30

Table 10. Calibrated RTI parameters for WYs 2016, 2017, and

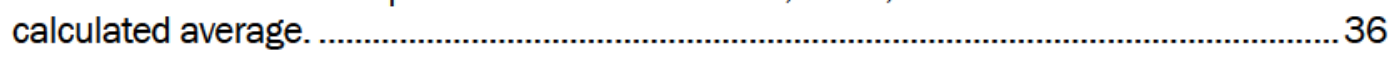

Table 11. RTI snowmelt model calibration statistics.......................................................... 38

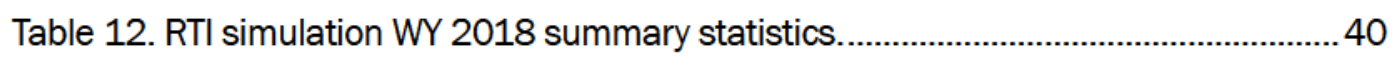

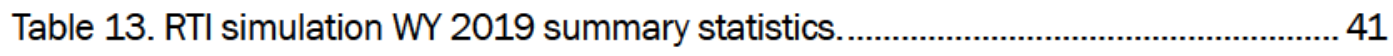

Table 14. RTI simulation WY 2020 statistics.................................................................. 43

Table 15. RTI and TI stream flow statistics for WYs 2016 and 2017.................................50 


\section{Preface}

This study was conducted for the Flood and Coastal System (FCS) under Funding Account Code U4368971, AMSCO Code 31398.

The work was performed by the Terrain and Ice Engineering Group of the Remote Sensing/GIS Center of Expertise, US Army Engineer Research and Development Center, Cold Regions Research and Engineering Laboratory (ERDC-CRREL). The work was also performed by the River Engineering Branch of the Flood and Storm Protection Division, Engineer Research and Development Center, Coastal and Hydraulics Laboratory (ERDCCHL), and by the Hydrologic Engineering Center, US Army Corps of Engineering (USACE-HEC). At the time of publication of this report, Dr. Meghan Quinn was team lead; Mr. David Finnegan was Chief at ERDC-CRREL; Mr. Matthew Fleming was chief of the Hydrology and Statistics Division; Mr. Chris Dunn was the Director of the USACE-HEC. The Deputy Director of ERDC-CRREL was Mr. David Ringelberg, and the Director was Dr. Joseph Corriveau. The Deputy Director of ERDC-CHL was Mr. Keith Flowers, and the Director was Dr. Ty V. Wamsley.

The Commander of ERDC was COL Teresa A. Schlosser, and the Director was Dr. David W. Pittman. 


\section{Introduction}

\subsection{Background}

The ability to simulate snow accumulation and melting processes is fundamental to developing real-time hydrological models in watersheds with a snowmelt-dominated flow regime. Models developed to meet this capability can generally be divided into two categories: (1) energy balance models that directly calculate heat fluxes from a solar radiation budget and (2) temperature index (TI) models that use thermal gradients to approximate heat fluxes at the snow-air interface. TI models are more widely used than energy balance models (e.g., Anderson 2006; Debele et al. 2009) because the data required to develop and calibrate energy balance models are not commonly collected at weather stations. Hock et al. (2003) found TI models forced by air temperature perform well in watersheds with high relief, where snow accumulation is positively correlated with elevation. The successful application of air temperature forced TI models for snow modeling is because air temperature is highly correlated with longwave radiation and sensible heat fluxes (Ohmura 2001). Air temperature forced TI models are, however, limited by their ability to simulate melt when the air temperature is close to freezing. To overcome this limitation, TI models can be parameterized to compensate for low gradient melting events. In addition, hybrid models that incorporate some aspects of the energy balance in the temperature index formulation have been developed.

Hydrologic models are typically calibrated to historical records of observed snow and streamflow using sets of model parameters (hereafter termed parameterization). A primary source of uncertainty with this model development approach is the subjectivity related to which historical periods to use and how to combine parameters from multiple calibration events. This process of parameter estimation can introduce additional uncertainty into results. In recent years, TI models have been developed using a radiation-based temperature metric (Follum et al. 2015). Conceptually, radiation temperature forced TI models will have fewer parameters than air temperature forced models because the internal calculations are more representative of the amount of energy available to melt snow. A complexity associated radiative temperature forced TI models is the requirement for high-resolution spatiotemporal meteorological datasets. These types of datasets have been developed for 
some time (e.g., 2010 - present) for aviation purposes but have not been used extensively in hydrologic modeling because early datasets were not historically archived.

The Hydrologic Engineering Center, Hydrological Modeling System (HECHMS), has recently implemented a hybrid temperature index snow module that has not been extensively tested. The Cold Regions Research and Engineering Laboratory has been tasked with evaluating the new module's performance relative to the traditional air temperature index model. In this report, we refer to the radiation temperature forced TI model using the abbreviation for radiative temperature index, RTI. Air temperature forced TI models will be referred as TI. A comparison between the widely used TI and new RTI models is presented in this report.

\subsection{Objective}

The primary objective of this study is to evaluate a newly implemented RTI model in HEC-HMS. The objectives of this study are the following:

- Apply the current RTI implementation in HEC-HMS to the Willow Creek watershed and compare it to the results of a TI model

- Provide recommendations for model improvements and data sources

- Perform sensitivity analysis of RTI parameters

- Discuss the potential application of the current RTI implementation for operational use at US Army Corps of Engineers (USACE) district offices.

\subsection{Approach}

Our approach to evaluating the RTI and TI snow models in HMS to Willow Creek involved calibrating the models to water years (WYs) 2016 and 2017. The calibration parameters for each model were used to determine a representative set of parameters to simulate WYs 2018-2020. The performance of each model was compared for the calibration and validation periods. The quantification of the performance was based on the Nash-Sutcliffe efficiency (NSE), root mean square error (RMSE), percent bias, of the peak snow water equivalent (SWE) magnitude and timing. The results of both models were compared, and differences were investigated and discussed. 


\section{Study Basin}

Willow Creek is a $637 \mathrm{mi}^{2}{ }^{*}{ }_{i}$ tributary to the Snake River located within southeastern Idaho (Figure 1). Ririe Dam (USACE 1966) and Reservoir provide both water supply and flood risk reduction for the Snake River valley. The study basin can be further divided into three subbasins. Water accumulates from Grays Lake and Ririe Upstream to Ririe Reservoir in the Ririe subbasin. The elevation distribution of each subbasin is generally flat (Figure 2), with a predominant National Landcover Classification Database (NLCD) classification of shrub/scrub (Figure 3). There are two Snow Telemetry (SNOTEL) sites within the vicinity of Willow Creek that are located in areas with NLCD classifications of evergreen forest.

Figure 1. Willow Creek subbasin delineation and location map.

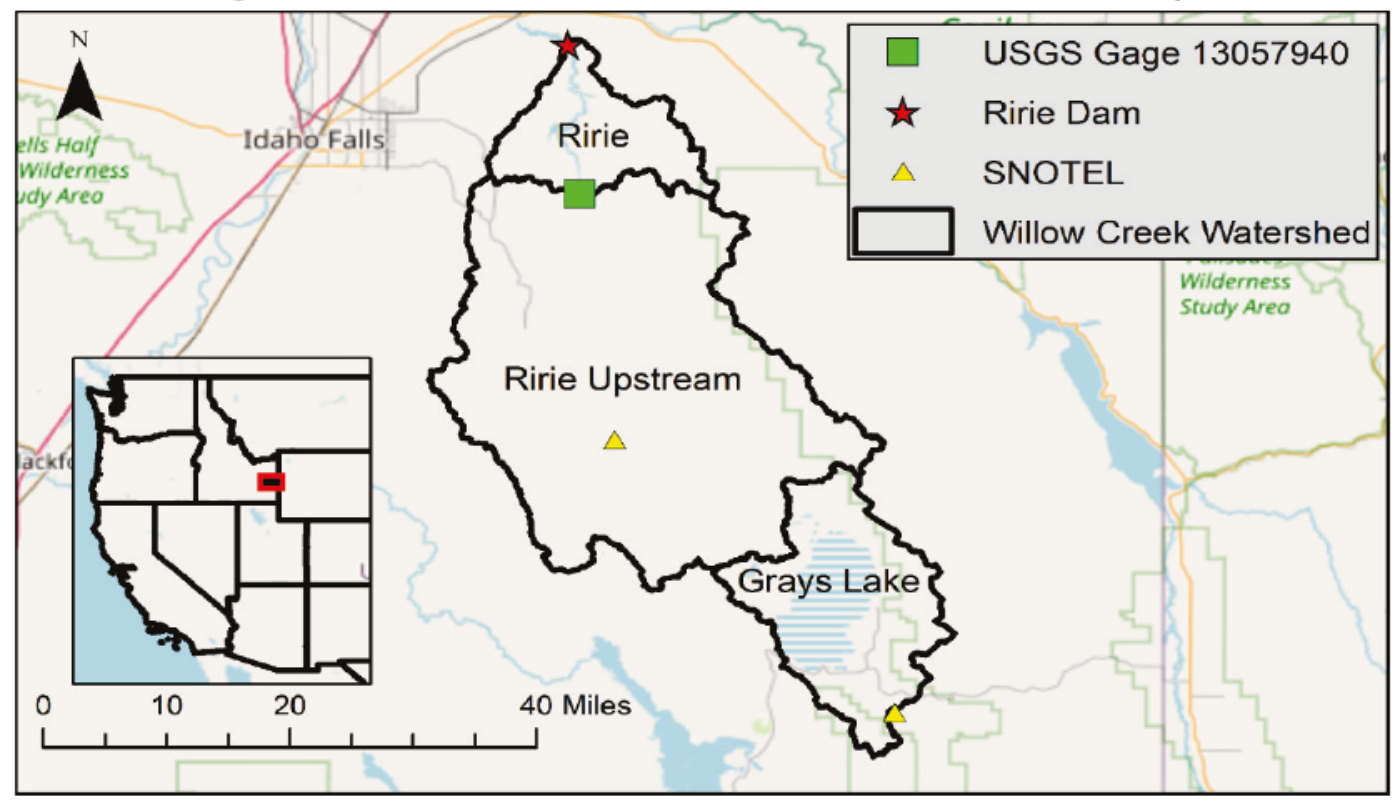

* For a full list of the spelled-out forms of the units of measure used in this document, please refer to US Government Publishing Office Style Manual, 31st ed. (Washington, DC: US Government Publishing Office 2016), 248-52, https:/www.govinfo.gov/content/pkg/GPO-STYLEMANUAL-2016/pdf/GPOSTYLEMANUAL-2016.pdf

† For a full list of the unit conversions used in this document, please refer to US Government Publishing Office Style Manual, 31st ed. (Washington, DC: US Government Publishing Office 2016), 345-7. https://www.govinfo_gov/content/pkg/GPO-STYLEMANUAL-2016/pdf/GPO-STYLEMANUAL-2016.pdf. 
Figure 2. Subbasin hypsometric curves for Willow Creek calculated from the National Elevation Dataset (Gesch et al. 2018).

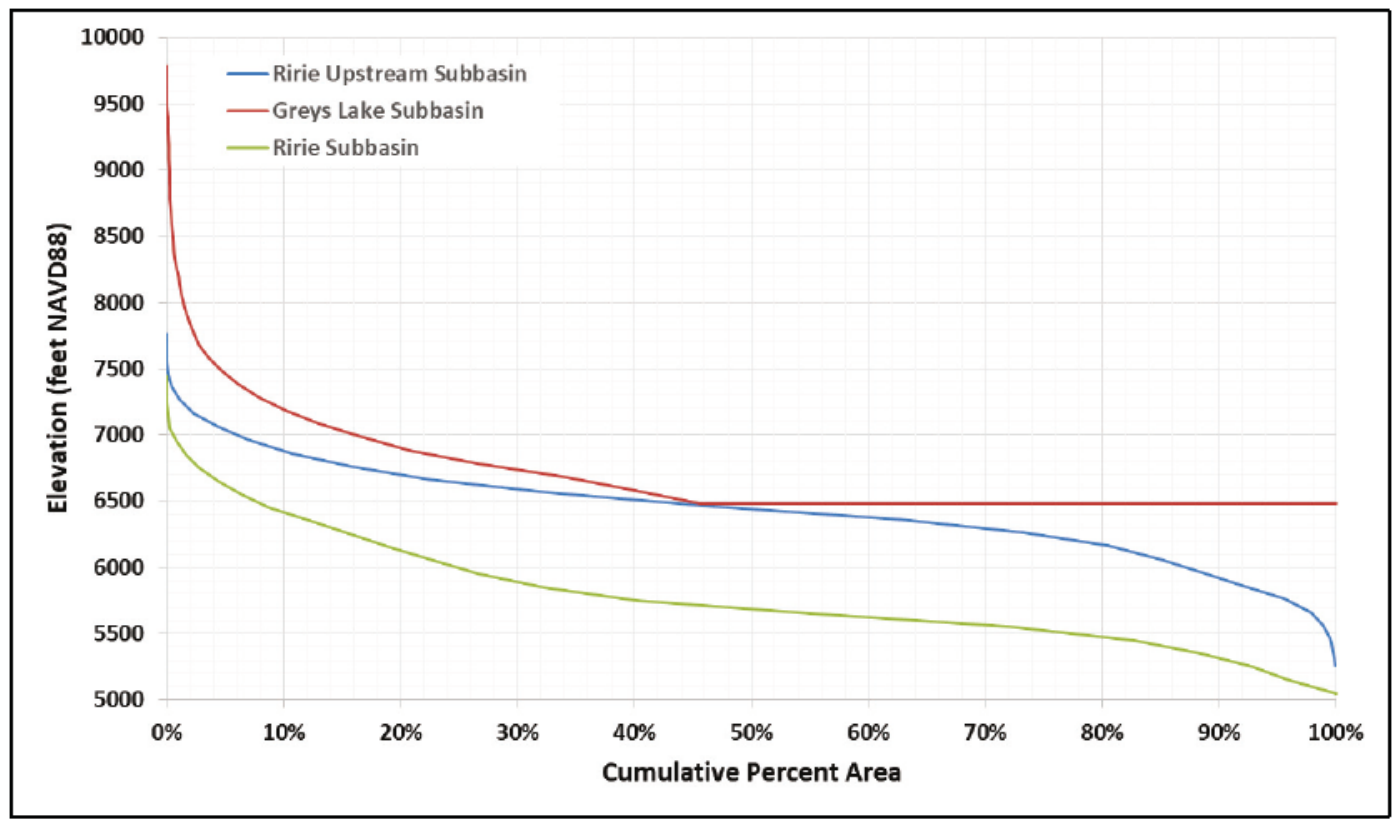

Figure 3. NLCD 2016 land classifications for Willow Creek watershed.

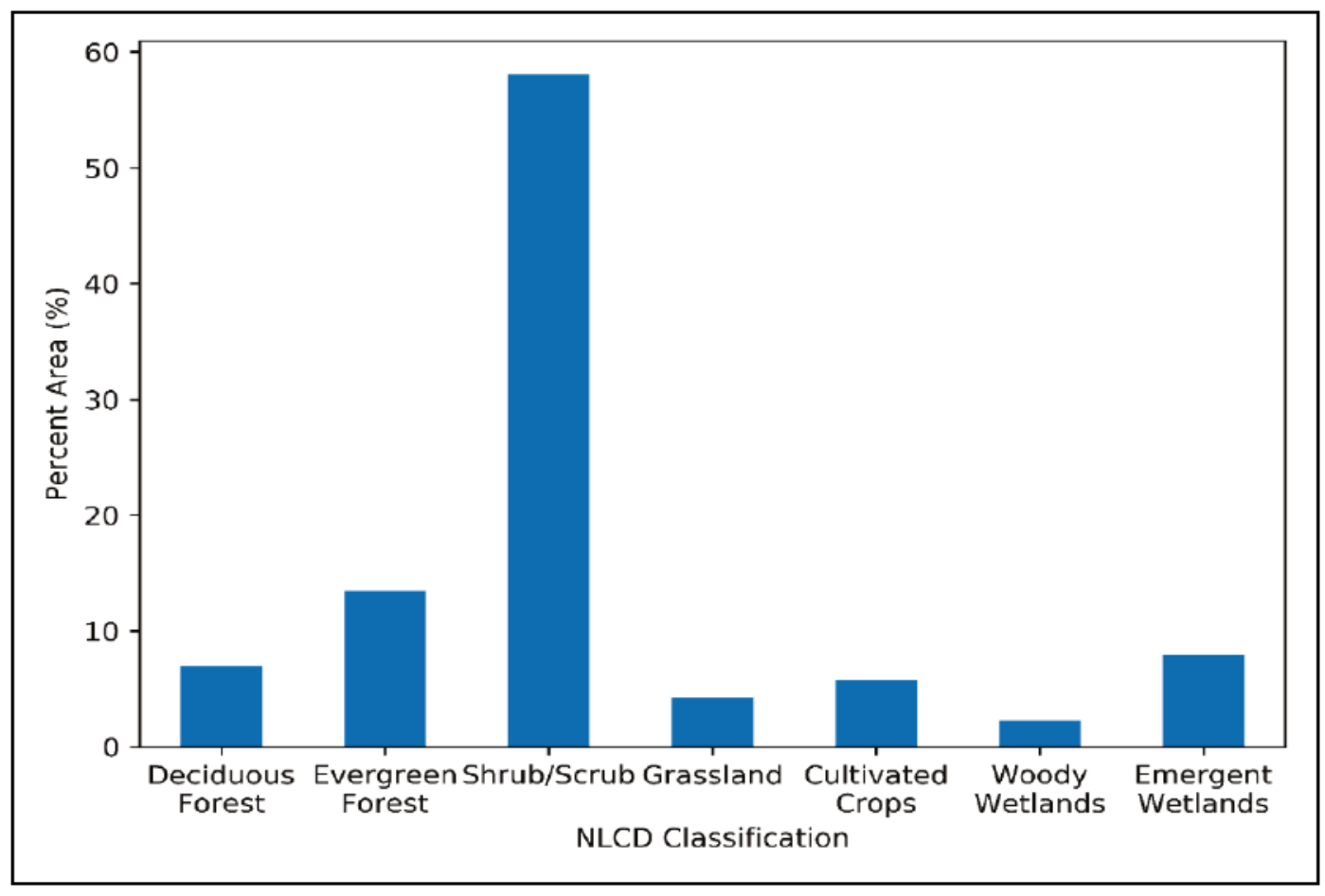


The climate of Willow Creek is characterized by hot and dry summers followed by cold winters (Giovando et al. 2020). The largest precipitation events are attributed to atmospheric rivers that transport water vapor from the Pacific Ocean. The predominant flood mechanisms in Willow Creek watershed are dominated by snowmelt runoff in mid to late spring. Large winter events can also occur when atmospheric rivers (e.g., Dettinger 2013) combine with frozen ground to produce enhanced runoff (Thomas and Lamke 1962). 


\section{Data Sources}

Precipitation and temperature data are the primary forcing variables for temperature index-based snowmelt hydrologic models. The RTI and TI models use precipitation and air temperature data to determine the phase of precipitation inputs (i.e., snow, rain, or a mixture). Air temperature is also used to approximate the internal temperature of a snowpack in both models. The TI model used the air temperature data to quantify melting at the snow-air surface while the RTI uses air temperature data in the formulation of the radiative temperature metric. The resulting radiative temperatures are used to simulate melting at the snow-air interface in the RTI model. In this study, we developed a $1 \mathrm{hr}$ georeferenced Hydrological Modeling System (HMS) model for WYs 2016 to 2020 using temperature data from the Real-Time Mesoscale Analysis (RTMA) and precipitation data from the Multi Radar MultiSensor (MRMS). The University of Arizona (UA) daily SWE grids were used to calibrate and validate the HMS model runs.

\subsection{Temperature data}

RTMA is a high spatial and temporal resolution dataset produced by the National Oceanic and Atmospheric Administration (NOAA)/National Centers for Environmental Prediction to support real-time operational hydrological forecasting (De Pondeca et al. 2011). The dataset consists of hourly $2.5 \mathrm{~km}$ grids of near-surface meteorological variables that have been assimilated from ground-based stations and satellite data. In this study, we used hourly temperature data for WYs 2016-2020 (Figure 4). The data are available operationally for the previous 10 days directly from NOAA, but the majority of the data has been archived by the Iowa State Environmental Mesonet servers (Mesonet 2020). 
Figure 4. Hourly average RTMA air temperature time series for Willow Creek watershed.

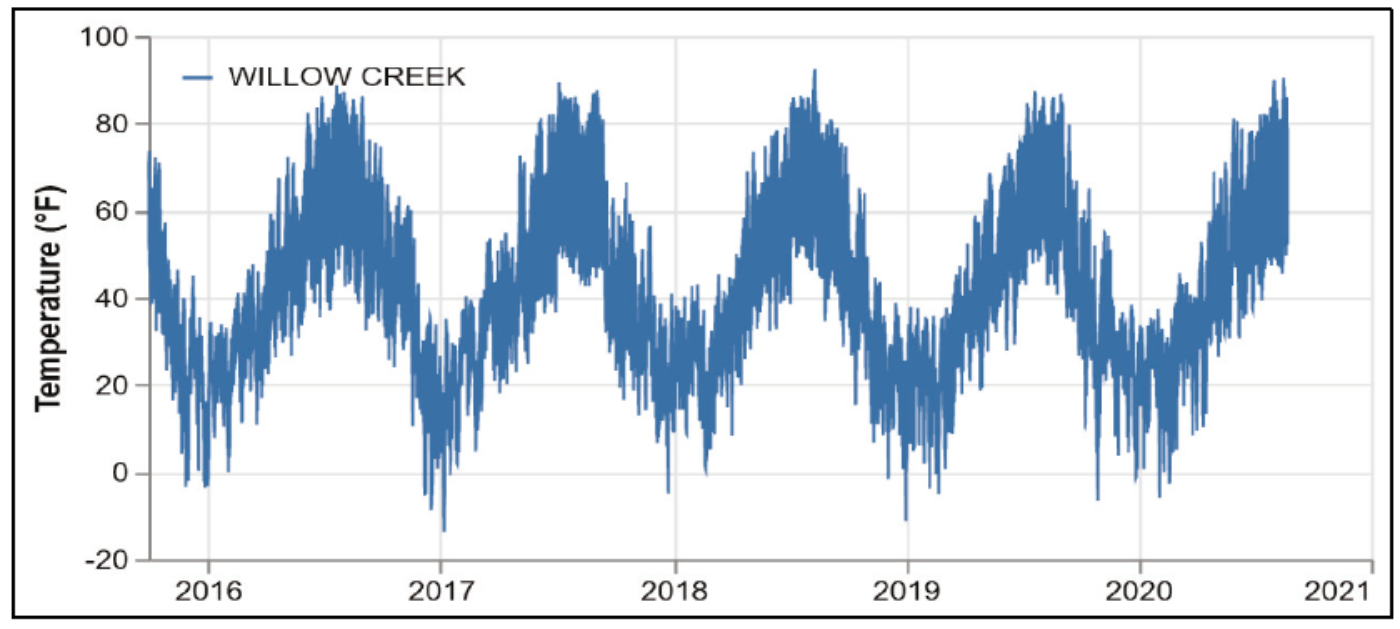

\subsection{Precipitation}

MRMS is an hourly dataset that integrates data from multiple radar systems, satellite, and forecast models into a $1 \mathrm{~km}$ gridded image (Zhang et al. 2016). The quality of the radar in the vicinity of Willow Creek is dependent on radar beam blockage by complex terrain, vertical resolution in radar beam geometry, and low-level cloud structures. In this study, we used the gage-corrected quantitative precipitation estimate (QPE) product for the precipitation forcing data (Figure 5). The native horizontal and vertical resolution of the QPE grids is $1 \mathrm{~km}$ and $1.1 \mathrm{~km}$, respectively. The data were downloaded from the Iowa State Mesonet servers (Mesonet 2020).

Figure 5. Cumulative precipitation curves for WYs 2015-2020 averaged over the Willow Creek watershed.

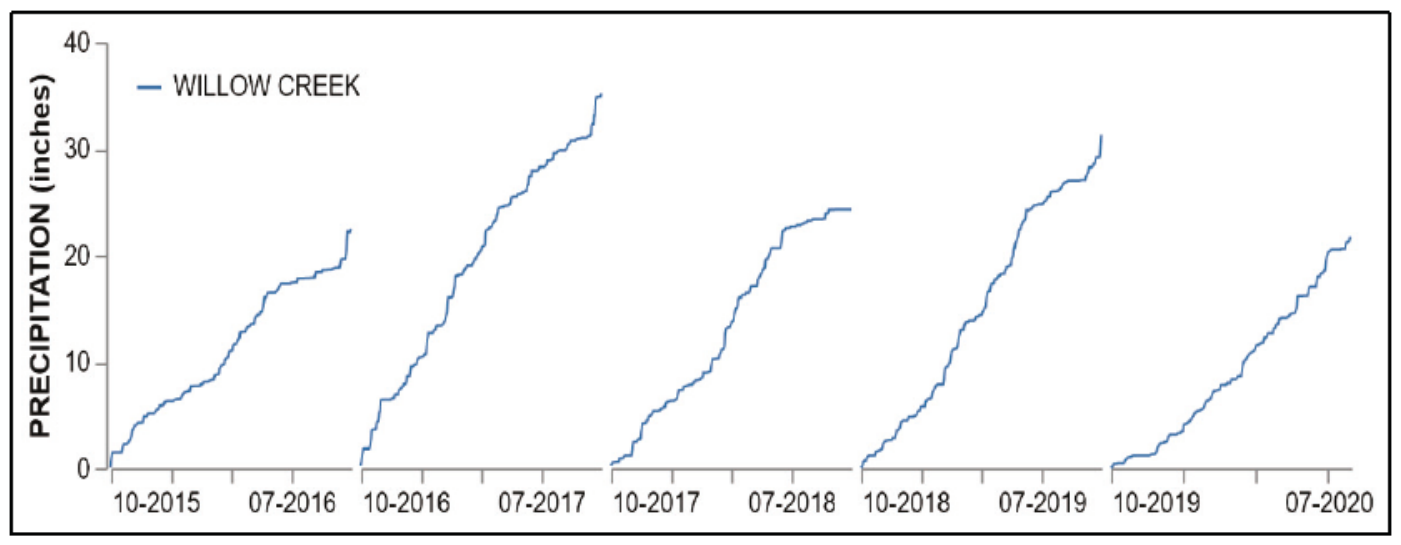


The MRMS QPE grids were converted to basin-averaged values to determine if the MRMS provides realistic precipitation estimates across the Willow Creek watershed (Figure 6). The basin-averaged cumulative precipitation depths curves show, surprisingly, that the higher-elevation basins have less cumulative precipitation throughout the year than the lower-elevation basins. Giovando et al. (2020) examined the historical record of precipitation in the vicinity of Willow Creek and found the opposite trend where cumulative precipitation depths increased with elevation.

Figure 6. Subbasin averaged cumulative precipitation for WY 2016.

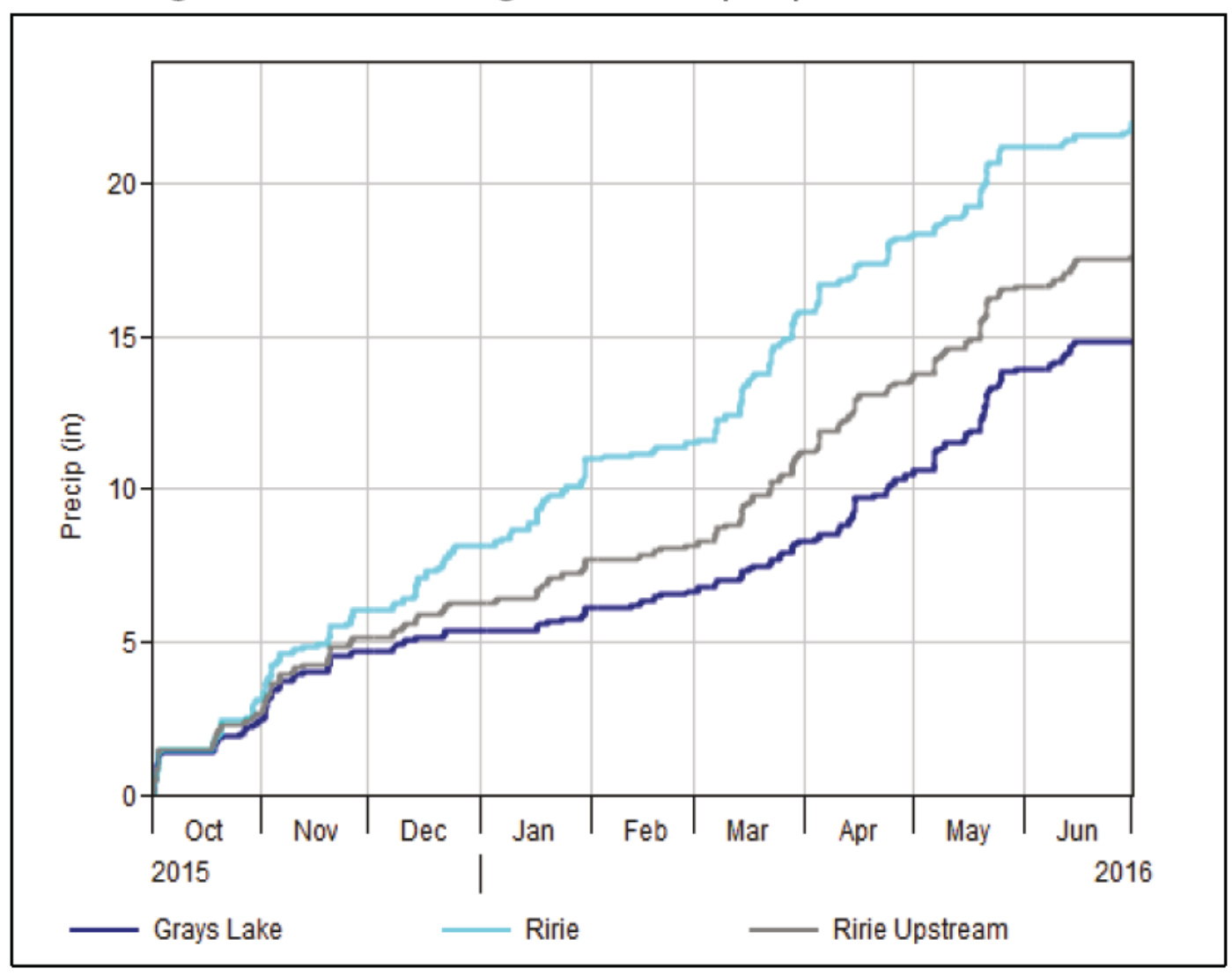

The trend of more precipitation at lower elevations persisted across the entire time series and is most likely attributed to the gauge corrections applied to the dataset (Figure 7). The MRMS QPE dataset used in our study corrects the radar with real-time observations from the Hydrometeorological Automated Data System (HADS). For our study area, the HADS data are exclusively in the lower elevation areas near the Snake River valley. Therefore, when the corrections are applied to the radar image using an inverse distance weighting with fixed parameters (De Pondeca et al. 2011), most of the correction is applied to pixels near the 
Ririe subbasin. Figure 7 shows that the magnitude of the gauge correction artifacts varies through time but significantly influences the quality of the product in Willow Creek.

Figure 7. Cumulative precipitation depth maps showing the gauge correction artifacts in the MRMS gauge corrected QPE grids in Willow Creek. The blue areas indicate anomalously high precipitation.

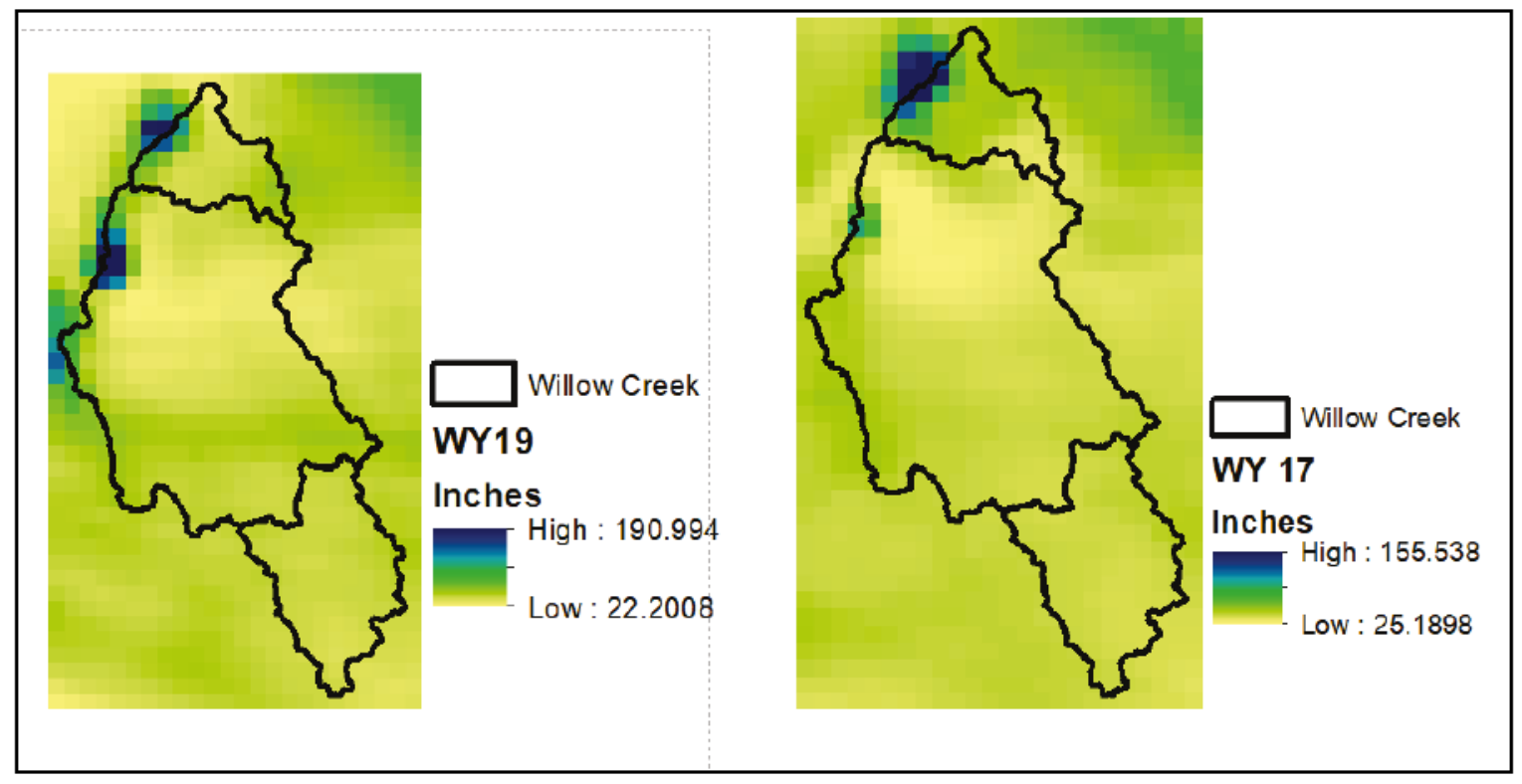

To address this issue with the precipitation data, the raw MRMS gauge corrected QPE time series was normalized using the daily precipitation grids from Parameter-elevation Regressions on Independence slopes model (PRISM) (Daly et al. 2008; PRISM 2020). PRISM uses a local climate-elevation relationship and observation data to create a $4 \mathrm{~km}$ gridded product that has demonstrated accuracy in complex topography. The raw MRMS data were normalized to the PRISM data using a 7-day accumulation period (Figure 8). The normalization procedure has the largest effect in the Ririe subbasin but results in a trend of increasing precipitation depth with elevation that agrees with Giovando et al. (2020) precipitation and SWE analyses of Willow Creek. Hereafter, MRMS data normalized to PRISM is denoted as MRMS. 
Figure 8. Normalized MRMS subbasin averaged cumulative precipitation depths for WY 2016.

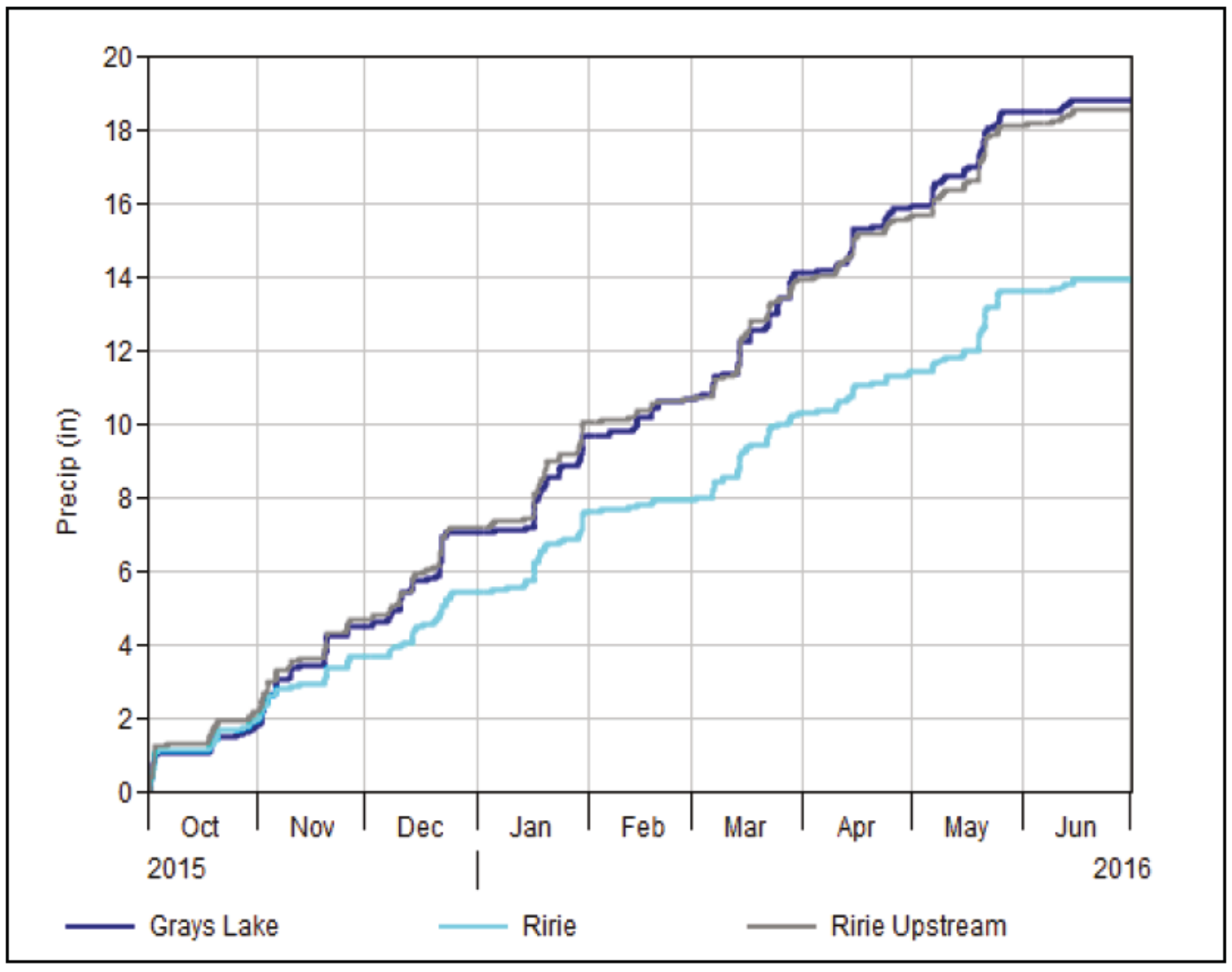

\subsection{SWE}

The UA produces a daily $4 \mathrm{~km}$ gridded dataset of SWE (Zeng et al. 2018 that is developed using ground SWE observations from SNOTEL and Cooperative Observer Network weather stations and daily precipitation from PRISM. Giovando et al. (2020) analyzed SWE trends in Willow Creek and found the UA dataset to produce more realistic SWE distributions than the Snow Data Assimilation System. The UA SWE data have been published for WYs 2015-2017 and were downloaded from the National Snow and Ice Data Center (Broxton 2019). Unpublished UA data for WYs 2018-2020 were downloaded directly from the UA servers (Broxton 2020). Figure 9 shows the subbasin averaged SWE time series for WY 2016-2020. 
Figure 9. UA SWE subbasin averaged time series.

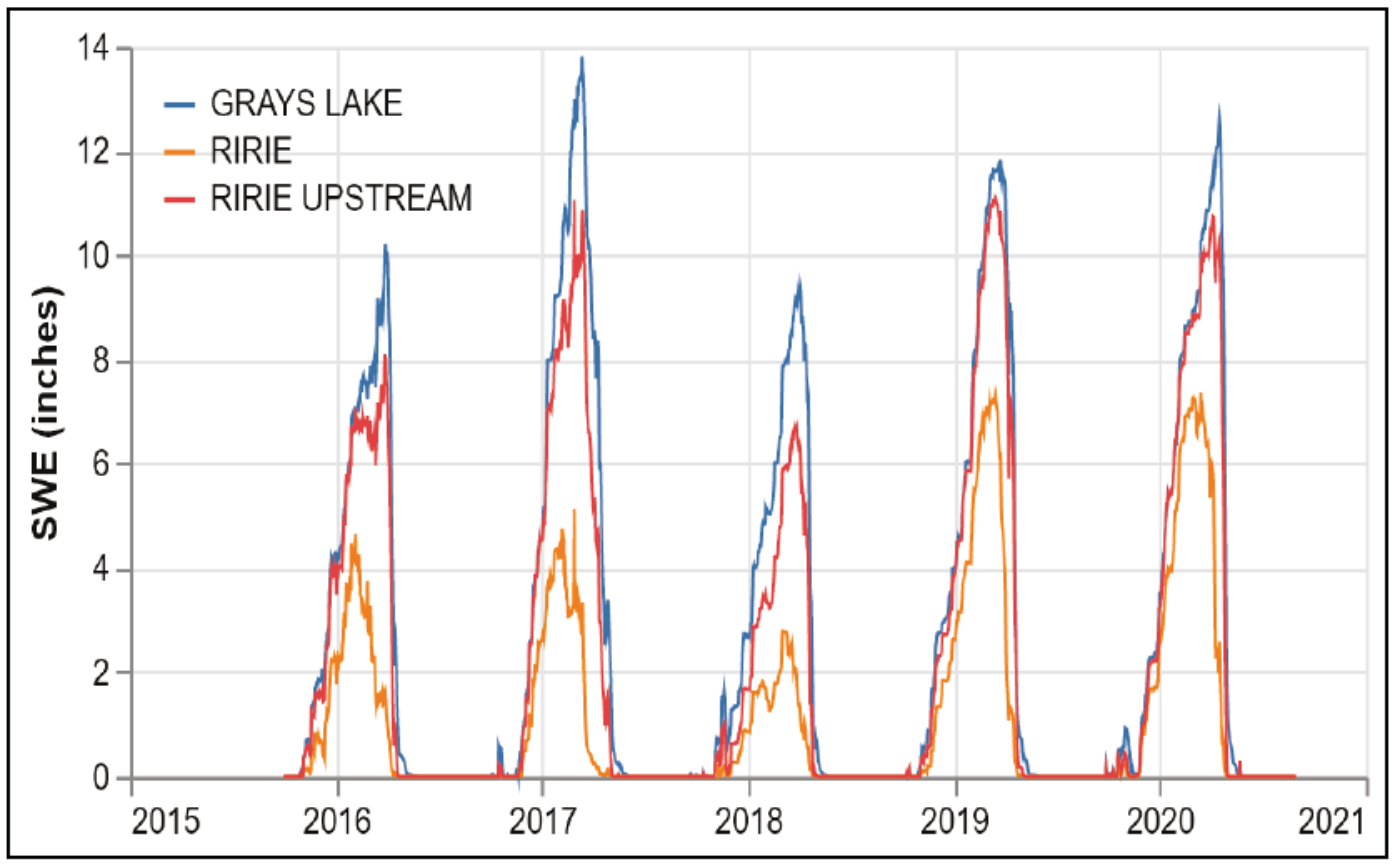

\subsection{Data processing}

All of the spatial data were post-processed to create a $2 \mathrm{~km}$ georeferenced model on a standard hydrologic grid projection (SR-ORG:6703). The time series of gridded weather variables was converted to HEC Data Storage System (DSS) format using the "Vortex" utility (Brauer and Van 2020). All geoprocessing tools encoded within Vortex are built upon Geospatial Data Abstraction Library processing utilities (GDAL 2021). The Vortex Normalizer utility performs a cell-by-cell scaling MRMS data to coincident PRISM data. The HMS modeling domain used in this study is described in Table 1.

Table 1. HMS model geographic information system (GIS) metadata.

\begin{tabular}{|l|l|}
\hline HMS Model GIS Metadata & -640 \\
\hline Lower Left CellX & 1156 \\
\hline Lower Left CellY & 24 \\
\hline Number of CellsX & 41 \\
\hline Number of CellsY & 2000 \\
\hline Cell Size & NAD83 \\
\hline Projection Datum & meters \\
\hline Projection Units & 29.5 \\
\hline First Standard Parallel &
\end{tabular}




\begin{tabular}{|c|c|}
\hline \multicolumn{2}{|l|}{ HMS Model GIS Metadata } \\
\hline Second Standard Parallel & 45.5 \\
\hline Central Meridian & -96.0 \\
\hline Latitude of Projection Origin & 23.0 \\
\hline False Easting & 0.0 \\
\hline False Northing & 0.0 \\
\hline XCoord of Grid Cell Zero & 0.0 \\
\hline YCoord of Grid Cell Zero & 0.0 \\
\hline PROJ 4 & $\begin{array}{l}\text { +proj=aea +lat_1 }=29.5+\text { lat_2 }=45.5 \\
\text { +lat_0 }=37.5+\text { +lon_0 }=-96+x \_0=0 \\
\text { +y_0 }=0+\text { ellps }=\text { GRS } 80+\text { +datum=NAD83 } \\
\text { +units }=\text { m no_defs }\end{array}$ \\
\hline
\end{tabular}




\section{Hydrological Modeling System (HMS) Model Modifications}

The HMS model used in this study was originally developed by the USACE, Walla Walla District. The HMS model was converted from a basin-averaged lumped process to a fully distributed, gridded model using a $30 \mathrm{~m}$ digital elevation model (DEM) from the National Elevation Dataset (Gesch et al. 2018) using HEC-HMS version 4.7 (Figure 10). The Grays Lake subbasin is included in the model for snowmelt modeling but was not considered for runoff comparisons because it includes an intra-basin diversion and generally does not provide any runoff contributions to Ririe Reservoir during floods.

Figure 10. HMS basin model for Willow Creek.

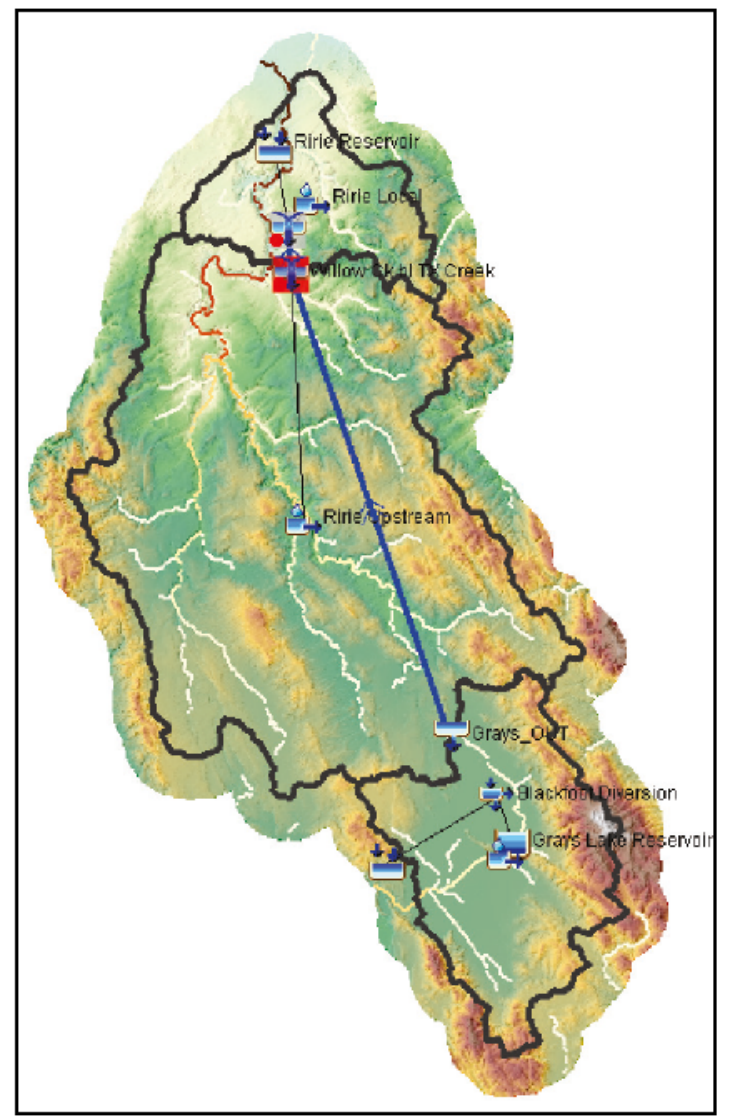

The terrain data were also used to calculate topographic shading, which is a derivative DEM product that relates the slope and aspect of neighboring cells. The topographic shading information is required to estimate solar radiation components at the ground surface for the RTI model. These topographic preprocessing calculations were calculated in HMS version 4.7 and took approximately 7 hours on a laptop. 


\section{$5 \quad$ Temperature Index (TI) Model}

The TI snowmelt model in HEC-HMS estimates the following snowpack properties at each time-step: SWE accumulated in the snowpack; the snowpack temperature (actually, the snowpack cold content, but this is proxy snowpack energy); snowmelt (when appropriate); the liquid water content of the snowpack; and finally, the runoff at the base of the snowpack. The TI model implementation is based on USACE (1987).

Snow is accumulated on a grid cell when there is a precipitation event with an air temperature below a threshold temperature $\left(T_{P X}\right)$. The model simulates the temperature of the snowpack surface using an accumulated temperature index (ATICC, Equation 1), which is used to approximate heat exchanges at the snowpack air interface between timesteps $t=1$ and $t=2$.

$$
\operatorname{ATICC}_{2}=\operatorname{ATICC}_{1}+\left(1-\left(1-\operatorname{TIPM}_{2}\right)^{1 / 24}\right)\left(T_{a, 2}-\operatorname{ATICC}_{1}\right)
$$

where $T_{a}$ is the air temperature and TIPM is a coefficient specified in the model. The formulation of Equation 1 assumes that air temperature is in degrees Centigrade, but the same formulation can be used for degrees Fahrenheit if $T_{a}$ is replaced by the quantity $\left(T_{a}-T_{b}\right)$, where $T_{b}$ is the temperature where water changes between liquid and solid phase.

Recommended values for the non-dimensional TIPM parameter are 0.2 for shallow snowpacks and 0.5 for deep snowpacks (USACE 2017). Larger values of TIPM result in a calculation that have a stronger correlation with diurnal air temperature fluctuations. By definition, ATICC can only be accumulated when $T_{a}$ is below freezing. When ATICC. $_{2}$ results in a positive number, ATICC is held at zero until the budget begins to accumulate negative values. The model simulates changes in snowpack internal temperatures using cold content $(c c)$. The formulation for the changes in $c c$ between $t=1$ and $t=2$ in Equation 2:

$$
c c_{2}=c c_{1}-\frac{c_{r}\left(1-T I P M_{2}\right)^{1 / 24}}{\log \left(1-T I P M_{2}\right)}\left(T_{a}-\operatorname{ATICC}_{1}\right)
$$

The cold rate coefficient $\left(c_{r}\right)$ is a coefficient that influences how closely the internal temperature of the snowpack correlates with changes in air temperature. Recommended values for $c_{r}$ range from 0.01 to 0.028 in. $/{ }^{\circ} \mathrm{F} /$ day, with the most common choice being $0.02 \mathrm{in} . /{ }^{\circ} \mathrm{F} /$ day (USACE 2017). 
Snowmelt is also simulated using an accumulated temperature index approach. The antecedent temperature melt index is calculated using Equation 3.

$$
A T I M R=A T I M R_{1} a^{1 / 24}+T_{a}(1 / 24)
$$

where $a$ is a melt rate coefficient that is typically set to 0.98 (USACE 2017). By definition, ATIMR can only accumulate when $T_{a}$ is above freezing. The amount of snowmelt $(M)$ is calculated using a melt factor $\left(M_{f}\right) . M_{f}$ is parameterized in the TI model for dry and wet melt events. During wet melt events, the amount of heat available from melting increases when liquid precipitation is falling on a snowpack. Regardless of the melting event type, melt factors can be parameterized as a constant value or varied seasonally using a lookup table between ATIMR and $M_{f}$. A simplified melt equation is presented in Equation 4, but $M_{f}$ is allowed to vary if it was parameterized as a function of ATIMR.

$$
M=M_{f} T_{a}
$$

Figure 11 is a flow chart showing how surface melt and liquid precipitation are converted to liquid water at the soil surface. The process of releasing water from a snowpack is determined by relating the amount of surface melt and liquid precipitation (Equation 4) to the liquid water holding capacity of the snowpack and the cold content. The liquid water holding capacity of the snowpack is used to determine if there is potential surface runoff. There are three scenarios accounted for in the temperature index implementation in HEC-HMS. First, the snowpack can store the meltwater in the snowpack (snowpack temperature below freezing). Second, a fraction of the melt is held internally in the snowpack, and the remainder is available as potential runoff. Third, the snowpack is isothermal at freezing temperature, as all of the melt is available as potential runoff.

The amount of potential runoff that is converted to actual runoff is determined by the cold content (Equation 2) of the snowpack. When $c c$ is available, precipitation on the snow surface or surface melt to the snowpack can freeze when $c c$ is larger than the potential runoff. When $c c$ is only slightly positive, any precipitation or surface melt can partially freeze and rest is available as potential runoff. Finally, if $c c$ is at zero, all precipitation and surface melt is entirely be converted to liquid water at the soil surface. When some or all of the potential runoff can freeze, the 
melt is accumulated in the snowpack as SWE. As a result, $c c$ is reduced to reflect the amount of heat introduced in the snowpack associated with freezing liquid water.

Figure 11. TI flow chart for converting surface melt and liquid precipitation to liquid water at the soil surface.

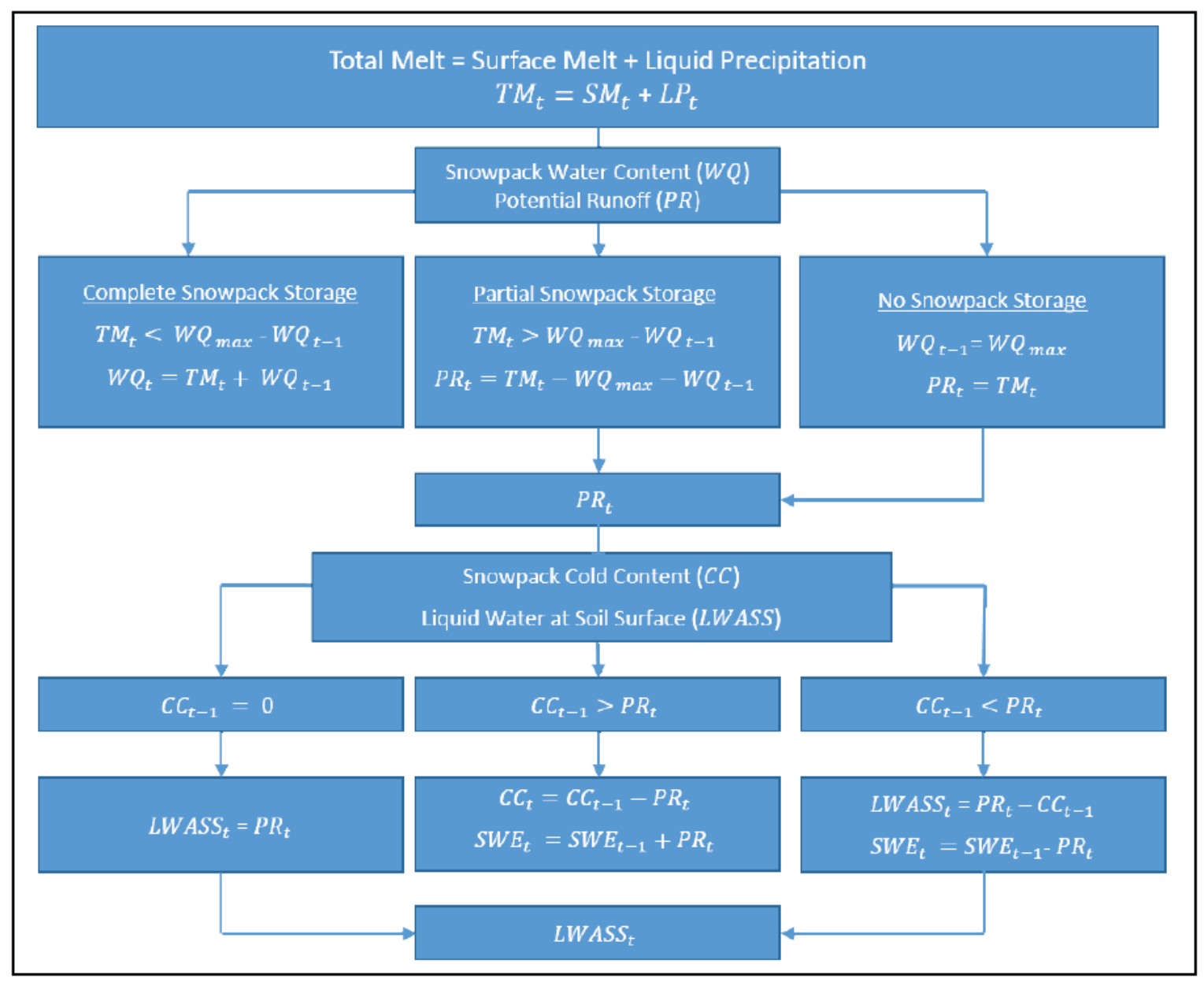

\subsection{TI model calibration}

WYs 2016 and 2017 were selected for model calibration. Each subbasin was calibrated to the UA SWE dataset. The resulting calibration parameters for WYs 2016 and 2017 are shown in Table 2 and Table 3, respectively. The phase temperature $\left(T_{P X}\right)$ was used as a calibration parameter to match the modeled magnitude of peak SWE to the observed data. 
Table 2. TI snowmelt calibration parameters for the WY 2016.

\begin{tabular}{|c|c|c|c|c|c|c|}
\hline \multicolumn{7}{|c|}{ Metrologic Model Summary } \\
\hline & \multicolumn{2}{|l|}{ Ririe } & \multicolumn{2}{|c|}{ Ririe Upstream } & \multicolumn{2}{|c|}{ Grays Lake } \\
\hline Snow TI Parameter & \multicolumn{2}{|c|}{ Value } & \multicolumn{2}{|c|}{ Value } & \multicolumn{2}{|c|}{ Value } \\
\hline PX Temp $\left({ }^{\circ} \mathrm{F}\right)$ & \multicolumn{2}{|l|}{35} & \multicolumn{2}{|c|}{33.5} & \multicolumn{2}{|l|}{35} \\
\hline Base Temp ( $\left.{ }^{\circ} \mathrm{F}\right)$ & \multicolumn{2}{|l|}{32} & \multicolumn{2}{|l|}{32} & \multicolumn{2}{|l|}{32} \\
\hline ATI Coefficient & \multicolumn{2}{|l|}{0.98} & \multicolumn{2}{|c|}{0.98} & \multicolumn{2}{|c|}{0.98} \\
\hline $\begin{array}{l}\text { Wet Meltrate (in. } /{ }^{\circ} \mathrm{F} \text { - } \\
\text { day) }\end{array}$ & \multicolumn{2}{|l|}{0.5} & \multicolumn{2}{|c|}{0.075} & \multicolumn{2}{|c|}{0.075} \\
\hline Rain Limit (in./day) & \multicolumn{2}{|l|}{0.05} & \multicolumn{2}{|l|}{0.3} & \multicolumn{2}{|l|}{0.3} \\
\hline \multirow[t]{5}{*}{ ATI Meltrate Function } & ATI & Melt Factor & ATI & Melt Factor & ATI & Melt Factor \\
\hline & 0 & 0.06 & 0 & 0.058 & 0 & 0.09 \\
\hline & 800 & 0.06 & 40 & 0.095 & 200 & 0.05 \\
\hline & & & 150 & 0.06 & 800 & 0.082 \\
\hline & & & 800 & 0.06 & & \\
\hline Cold Limit (in./day) & \multicolumn{2}{|l|}{0} & \multicolumn{2}{|l|}{0} & \multicolumn{2}{|l|}{0} \\
\hline Cold Rate Coefficient & \multicolumn{2}{|l|}{0.42} & \multicolumn{2}{|l|}{0.5} & \multicolumn{2}{|l|}{0.3} \\
\hline Water Capacity (\%) & \multicolumn{2}{|l|}{3} & \multicolumn{2}{|l|}{3.5} & \multicolumn{2}{|l|}{3} \\
\hline Groundmelt (in./day) & \multicolumn{2}{|l|}{0} & \multicolumn{2}{|l|}{0} & \multicolumn{2}{|l|}{0} \\
\hline
\end{tabular}

Table 3. TI snowmelt calibration parameters for the WY 2017.

\begin{tabular}{|c|c|c|c|c|c|c|}
\hline \multicolumn{7}{|c|}{ Metrologic Model Summary } \\
\hline & \multicolumn{2}{|l|}{ Ririe } & \multicolumn{2}{|c|}{ Ririe Upstream } & \multicolumn{2}{|c|}{ Grays Lake } \\
\hline Snow TI Parameter & \multicolumn{2}{|c|}{ Value } & \multicolumn{2}{|c|}{ Value } & \multicolumn{2}{|c|}{ Value } \\
\hline PX Temp ( $\left.{ }^{\circ} \mathrm{F}\right)$ & \multicolumn{2}{|l|}{35} & \multicolumn{2}{|c|}{32.1} & \multicolumn{2}{|l|}{35} \\
\hline Base Temp $\left({ }^{\circ} \mathrm{F}\right)$ & \multicolumn{2}{|l|}{32} & \multicolumn{2}{|l|}{32} & \multicolumn{2}{|l|}{32} \\
\hline ATI Coefficient & \multicolumn{2}{|l|}{0.98} & \multicolumn{2}{|c|}{0.98} & \multicolumn{2}{|c|}{0.98} \\
\hline Wet Meltrate (in. $/{ }^{\circ} \mathrm{F}$-day) & \multicolumn{2}{|l|}{0.45} & \multicolumn{2}{|c|}{0.17} & \multicolumn{2}{|c|}{0.075} \\
\hline Rain Limit (in./day) & \multicolumn{2}{|l|}{0.3} & \multicolumn{2}{|l|}{0.3} & \multicolumn{2}{|l|}{0.3} \\
\hline \multirow[t]{5}{*}{ ATI Meltrate Function } & ATI & Melt Factor & ATI & Melt Factor & ATI & Melt Factor \\
\hline & 0 & 0.05 & 0 & 0.03 & 0 & 0.12 \\
\hline & 50 & 0.05 & 100 & 0.075 & 100 & 0.05 \\
\hline & 800 & 0.6 & 250 & 0.05 & 800 & 0.082 \\
\hline & & & 800 & 0.06 & & \\
\hline Cold Limit (in./day) & \multicolumn{2}{|l|}{0} & \multicolumn{2}{|l|}{0} & \multicolumn{2}{|l|}{0} \\
\hline Cold Rate Coefficient & \multicolumn{2}{|l|}{0.3} & \multicolumn{2}{|c|}{0.42} & \multicolumn{2}{|l|}{0.4} \\
\hline Water Capacity (\%) & \multicolumn{2}{|l|}{3} & \multicolumn{2}{|l|}{3.5} & \multicolumn{2}{|l|}{3} \\
\hline Groundmelt (in./day) & \multicolumn{2}{|l|}{0} & \multicolumn{2}{|l|}{0} & \multicolumn{2}{|l|}{0} \\
\hline
\end{tabular}


The TI snowmelt calibration results for WYs 2016 and 2017 are shown in Figure 12 and Figure 13, respectively.

Figure 12. TI snowmelt calibration results for the WY 2016.

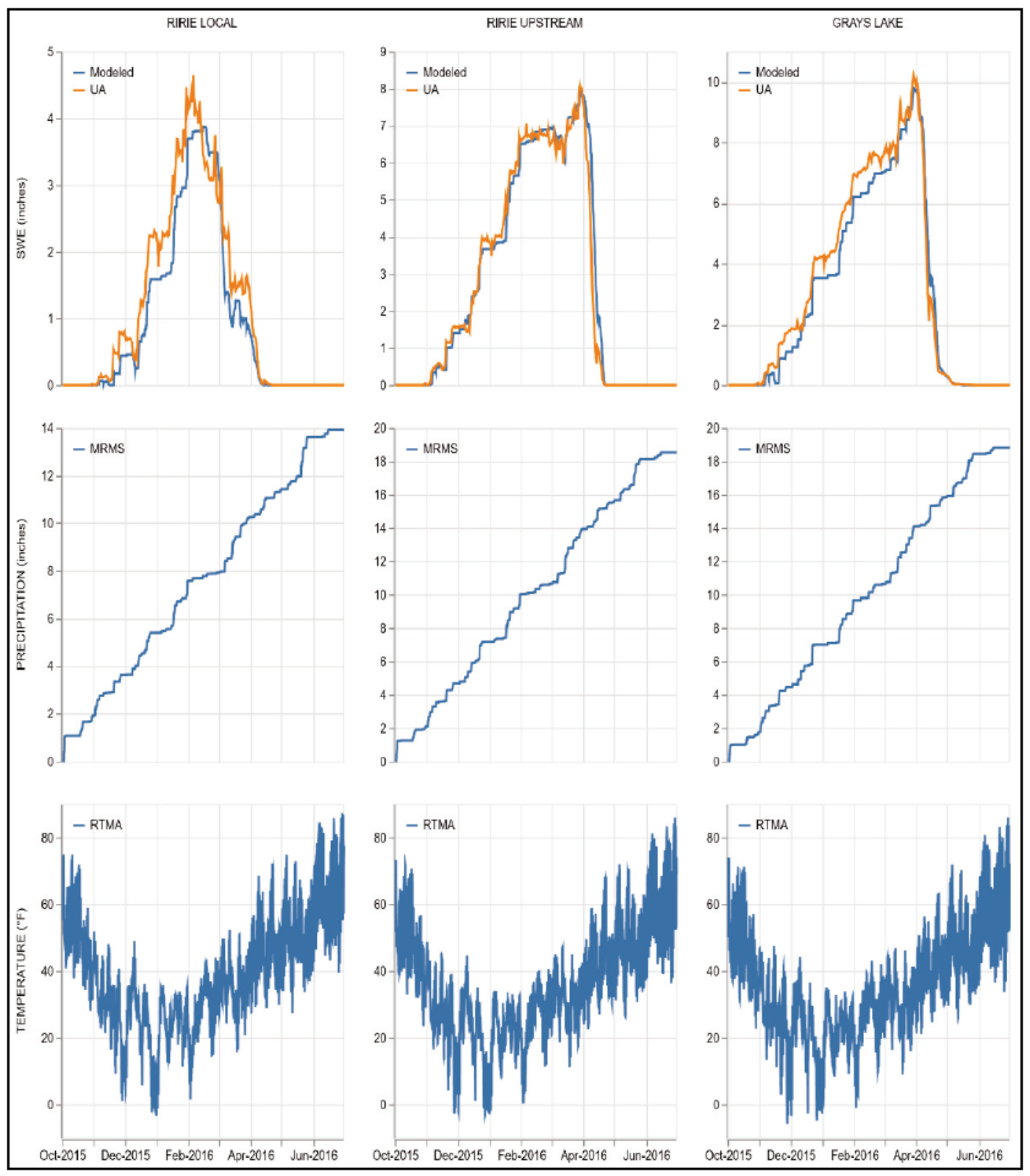


Figure 13. TI snowmelt calibration results for the WY 2017.

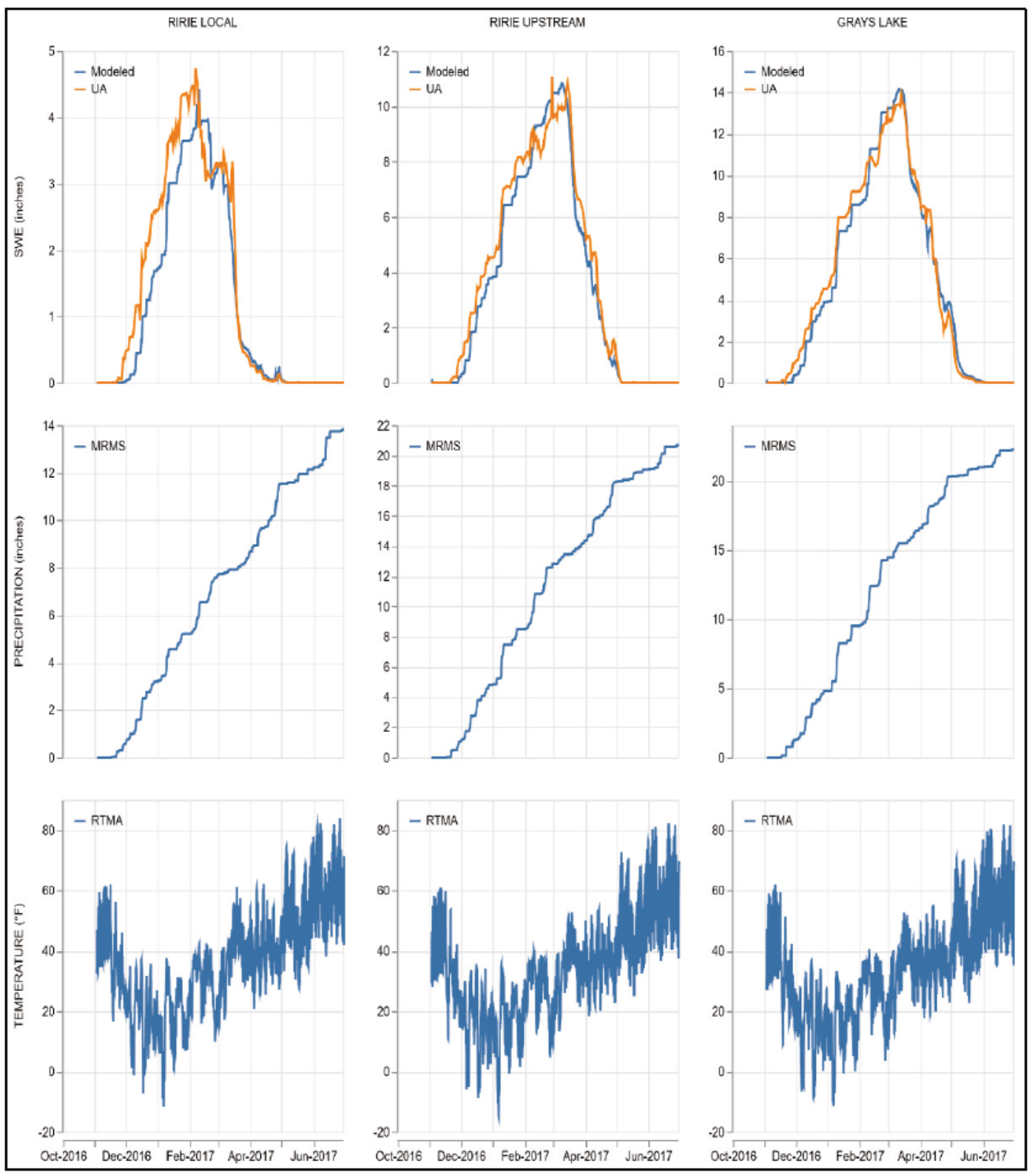


The Ririe subbasin snowmelt model had the largest bias and RMSE for both of the calibration years (Table 4). It consistently underpredicted the magnitude of SWE accumulation and overestimated the timing of the peak.

Table 4. TI snowmelt calibration statistics for WYs 2016 and 2017.

\begin{tabular}{|l|l|l|l|l|l|l|}
\hline & \multicolumn{3}{|c|}{ WY 2016 } & \multicolumn{3}{c|}{ WY 2017 } \\
\hline & Ririe & Ririe Upstream & Grays Lake & Ririe & Ririe Upstream & Grays Lake \\
\hline NSE & 0.92 & 0.974 & 0.974 & 0.916 & 0.972 & 0.984 \\
\hline Percent Bias & -18.38 & 1.93 & -8.16 & -16.39 & -7.8 & -2.77 \\
\hline RMSE & 0.28 & 0.16 & 0.16 & 0.29 & 0.17 & 0.16 \\
\hline Date Peak & $2 / 14 / 16$ & $3 / 29 / 16$ & $3 / 29 / 16$ & $2 / 10 / 17$ & $3 / 8 / 17$ & $3 / 11 / 17$ \\
\hline Observed Peak Date & $2 / 5 / 16$ & $3 / 28 / 16$ & $3 / 29 / 16$ & $2 / 6 / 17$ & $2 / 27 / 17$ & $3 / 13 / 17$ \\
\hline Peak SWE & 3.87 & 7.95 & 9.8 & 4.42 & 10.83 & 14.14 \\
\hline Observed Peak SWE & 4.65 & 8.09 & 10.22 & 4.75 & 11.06 & 13.81 \\
\hline
\end{tabular}

\subsection{TI model validation}

The model was validated with WYs 2018, 2019, and 2020 using three parameter sets for comparison purposes: the calibrated 2016, 2017, and an average of the 2 years. The parameters for the average of the 2 years, hereafter termed average, are shown in Table 5 .

Table 5. Average calibration parameters for TI model (average of 2016 and 2017 parameters).

\begin{tabular}{|c|c|c|c|c|c|c|}
\hline \multicolumn{7}{|c|}{ Metrologic Model Summary } \\
\hline & \multicolumn{2}{|l|}{ Ririe } & \multicolumn{2}{|c|}{ Ririe Upstream } & \multicolumn{2}{|c|}{ Grays Lake } \\
\hline Snow TI Parameter & \multicolumn{2}{|c|}{ Value } & \multicolumn{2}{|c|}{ Value } & \multicolumn{2}{|c|}{ Value } \\
\hline PX Temp $\left({ }^{\circ} \mathrm{F}\right)$ & \multicolumn{2}{|l|}{35} & \multicolumn{2}{|l|}{32.8} & \multicolumn{2}{|l|}{35} \\
\hline Base Temp $\left({ }^{\circ} \mathrm{F}\right)$ & \multicolumn{2}{|l|}{32} & \multicolumn{2}{|l|}{32} & \multicolumn{2}{|l|}{32} \\
\hline ATI Coefficient & \multicolumn{2}{|l|}{0.98} & \multicolumn{2}{|l|}{0.98} & \multicolumn{2}{|l|}{0.98} \\
\hline Wet Meltrate (in. $/{ }^{\circ} \mathrm{F}$-day) & \multicolumn{2}{|c|}{0.475} & \multicolumn{2}{|c|}{0.1225} & \multicolumn{2}{|c|}{0.075} \\
\hline Rain Limit (in./day) & \multicolumn{2}{|c|}{0.175} & \multicolumn{2}{|l|}{0.3} & \multicolumn{2}{|l|}{0.3} \\
\hline \multirow[t]{5}{*}{ ATI Meltrate Function } & ATI & Melt Factor & ATI & Melt Factor & ATI & Melt Factor \\
\hline & 0 & 0.055 & 0 & 0.044 & 0 & 0.115 \\
\hline & 50 & 0.05 & 75 & 0.085 & 100 & 0.05 \\
\hline & 800 & 0.06 & 150 & 0.06 & 800 & 0.06 \\
\hline & & & 800 & 0.06 & & \\
\hline Cold Limit (in./day) & \multicolumn{2}{|l|}{0} & \multicolumn{2}{|l|}{0} & \multicolumn{2}{|l|}{0} \\
\hline Cold Rate Coefficient & \multicolumn{2}{|l|}{0.36} & \multicolumn{2}{|l|}{0.46} & \multicolumn{2}{|l|}{0.35} \\
\hline Water Capacity (\%) & \multicolumn{2}{|l|}{3} & \multicolumn{2}{|l|}{3.5} & \multicolumn{2}{|l|}{3} \\
\hline Groundmelt (in./day) & \multicolumn{2}{|l|}{0} & \multicolumn{2}{|l|}{0} & \multicolumn{2}{|l|}{0} \\
\hline
\end{tabular}


The simulated SWE time series for the WY 2018 is shown in Figure 14 and summarized in Table 6 . There was minimal sensitivity to parameter selection during the simulated accumulation period before peak SWE. The primary differences are in the duration of the accumulation period before peak SWE. For Ririe Upstream, the highest NSE value of the 2018 validation simulations was using the 2017 calibration parameters. These parameters also produced the lowest RMSE along with a slight negative (low) bias in the peak SWE value.

Figure 14. TI model simulation SWE time series for the WY 2018.

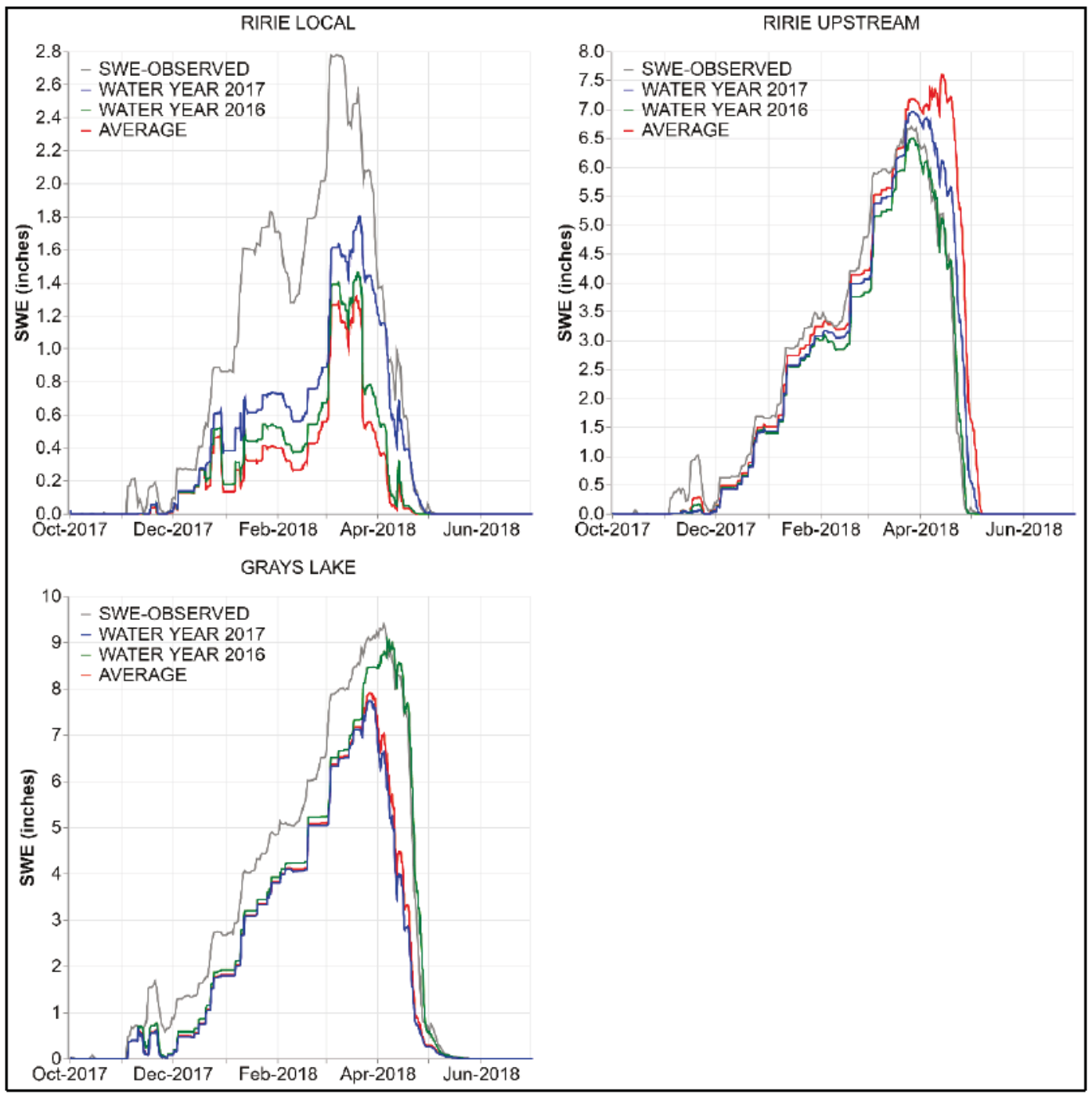


Table 6. TI model simulation statistics for WY 2018.

\begin{tabular}{|c|c|c|c|c|c|c|c|c|c|}
\hline \multirow{3}{*}{$\begin{array}{l}\text { Simulation } \\
\text { Calibration } \\
\text { Subbasin }\end{array}$} & \multicolumn{9}{|l|}{ WY 2018} \\
\hline & \multicolumn{3}{|l|}{ WY 16} & \multicolumn{3}{|l|}{ WY 17} & \multicolumn{3}{|l|}{ Average } \\
\hline & Ririe & $\begin{array}{l}\text { Ririe } \\
\text { Upstream }\end{array}$ & $\begin{array}{l}\text { Grays } \\
\text { Lake }\end{array}$ & Ririe & $\begin{array}{l}\text { Ririe } \\
\text { Upstream }\end{array}$ & Grays Lake & Ririe & $\begin{array}{l}\text { Ririe } \\
\text { Upstream }\end{array}$ & Grays Lake \\
\hline NSE & 0.328 & 0.97 & 0.947 & 0.607 & 0.935 & 0.817 & 0.178 & 0.817 & 0.847 \\
\hline RMSE & 0.82 & 0.17 & 0.23 & 0.63 & 0.26 & 0.43 & 0.91 & 0.43 & 0.39 \\
\hline Percent Bias & -64.06 & -10.98 & -15.48 & -46.32 & -1.62 & -30.86 & -70.71 & 9.23 & -28.9 \\
\hline Date Peak & $3 / 20 / 18$ & $3 / 27 / 18$ & $4 / 6 / 18$ & $3 / 21 / 18$ & $3 / 27 / 18$ & $3 / 27 / 18$ & $3 / 19 / 18$ & $4 / 13 / 18$ & $3 / 27 / 18$ \\
\hline $\begin{array}{l}\text { Observed } \\
\text { Peak Date }\end{array}$ & $3 / 7 / 18$ & $3 / 26 / 18$ & $4 / 4 / 18$ & $3 / 7 / 18$ & $3 / 26 / 18$ & $4 / 4 / 18$ & $3 / 7 / 18$ & $3 / 26 / 18$ & $4 / 4 / 18$ \\
\hline Peak SWE & 1.46 & 6.49 & 9.04 & 1.8 & 6.95 & 7.73 & 1.32 & 7.6 & 7.9 \\
\hline $\begin{array}{l}\text { Observed } \\
\text { Peak SWE }\end{array}$ & 2.78 & 6.7 & 9.39 & 2.78 & 6.7 & 9.39 & 2.78 & 6.7 & 9.39 \\
\hline
\end{tabular}


The simulated SWE time series for the WY 2019 is shown in Figure 15 and summarized in Table 7. There was minimal sensitivity to parameter selection during the simulated accumulation period before peak SWE. The primary differences are the peak SWE and melt rates during the ablation season. For Ririe Upstream, the highest NSE value of the 2019 validation simulations was using the 2016 calibration parameters. These parameters also produced the lowest RMSE along with a slight negative (low) bias in the peak SWE value.

Figure 15. TI model simulation SWE time series for the WY 2019.

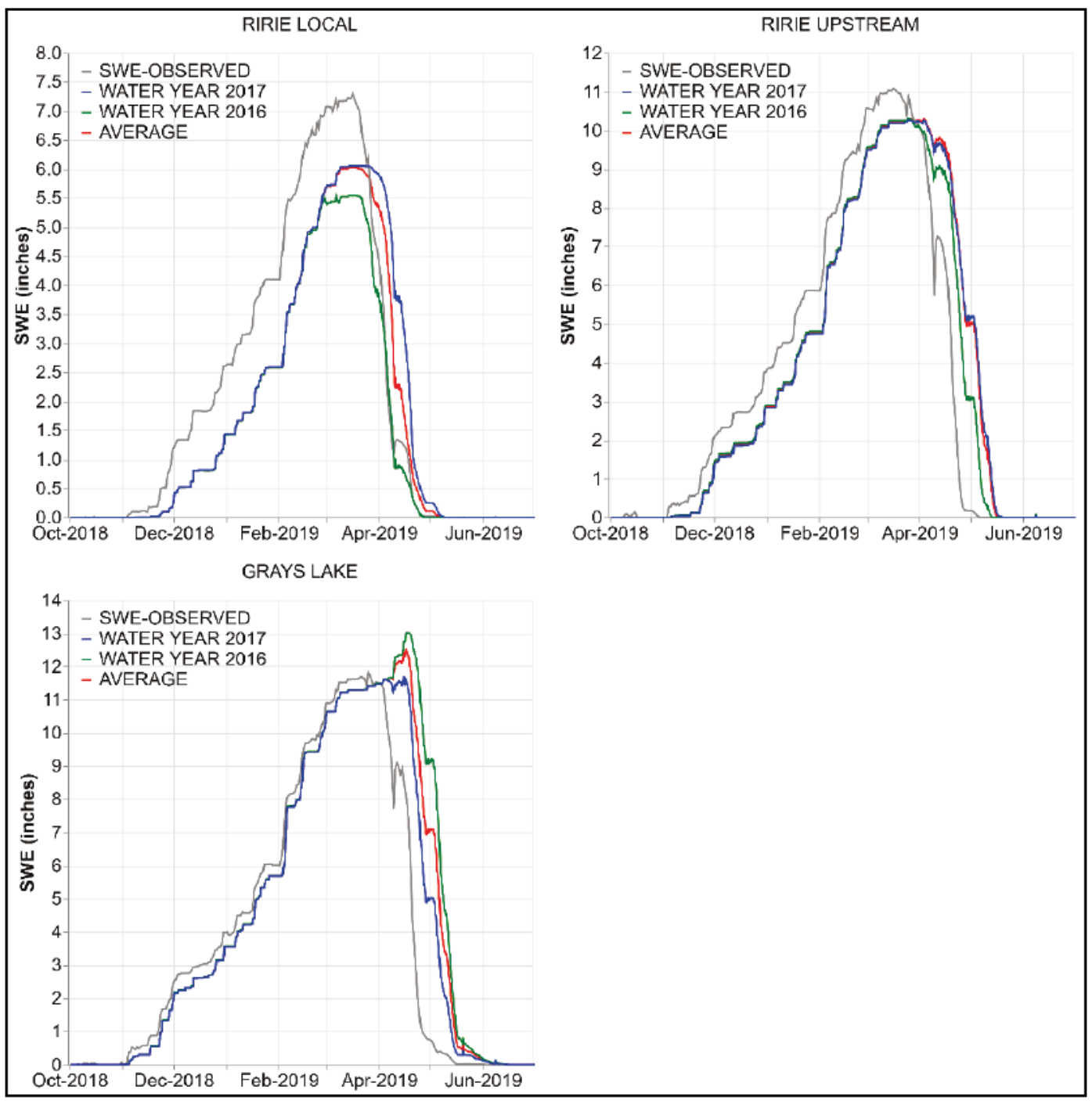


Table 7. TI model simulation statistics for the WY 2019.

\begin{tabular}{|c|c|c|c|c|c|c|c|c|c|}
\hline \multirow{3}{*}{$\begin{array}{l}\text { Simulation } \\
\text { Calibration } \\
\text { Subbasins }\end{array}$} & \multicolumn{9}{|c|}{ WY 2019} \\
\hline & \multicolumn{3}{|c|}{ WY 16} & \multicolumn{3}{|c|}{ WY 17} & \multicolumn{3}{|c|}{ Average } \\
\hline & Ririe & $\begin{array}{l}\text { Ririe } \\
\text { Upstream }\end{array}$ & $\begin{array}{l}\text { Grays } \\
\text { Lake }\end{array}$ & Ririe & $\begin{array}{l}\text { Ririe } \\
\text { Upstream }\end{array}$ & $\begin{array}{l}\text { Grays } \\
\text { Lake }\end{array}$ & Ririe & $\begin{array}{l}\text { Ririe } \\
\text { Upstream }\end{array}$ & $\begin{array}{l}\text { Grays } \\
\text { Lake }\end{array}$ \\
\hline NSE & 0.855 & 0.911 & 0.661 & 0.807 & 0.833 & 0.886 & 0.855 & 0.838 & 0.79 \\
\hline $\begin{array}{l}\text { Percent } \\
\text { Bias }\end{array}$ & -30.88 & -3.83 & 17.14 & -17.07 & 0.76 & 7.34 & -22.16 & 1.09 & 12.39 \\
\hline RMSE & 0.38 & 0.3 & 0.58 & 0.44 & 0.41 & 0.34 & 0.38 & 0.4 & 0.46 \\
\hline Date Peak & $3 / 14 / 19$ & $3 / 25 / 19$ & $4 / 16 / 19$ & $3 / 14 / 19$ & $4 / 3 / 19$ & $4 / 15 / 19$ & $3 / 14 / 19$ & $3 / 25 / 19$ & $4 / 16 / 19$ \\
\hline $\begin{array}{l}\text { Observed } \\
\text { Peak Date }\end{array}$ & $3 / 16 / 19$ & $3 / 16 / 19$ & $3 / 25 / 19$ & $3 / 16 / 19$ & $3 / 16 / 19$ & $3 / 25 / 19$ & $3 / 16 / 19$ & $3 / 16 / 19$ & $3 / 25 / 19$ \\
\hline Peak SWE & 5.54 & 10.31 & 13.02 & 6.05 & 10.27 & 11.68 & 6.02 & 10.3 & 12.5 \\
\hline $\begin{array}{l}\text { Observed } \\
\text { Peak SWE }\end{array}$ & 7.29 & 11.09 & 11.83 & 7.29 & 11.09 & 11.83 & 7.29 & 11.09 & 11.83 \\
\hline
\end{tabular}

The simulated SWE time series for the WY 2020 is shown in Figure 16 and summarized in Table 8 . There was minimal sensitivity to parameters selection during the simulated accumulation period before peak SWE. The primary differences are in the magnitude of peak SWE, where the WYs 2016 and 2017 accumulated more SWE. For Ririe Upstream, the highest NSE value of the 2020 validation simulations was using the 2017 calibration parameters. These parameters were very similar to the 2016 calibration parameters but produced less of a negative (low) bias in the peak SWE value. The large difference between the modeled peak SWE and UA data is likely because the MRMS data were normalized to PRISM using early and provisional releases. 
Figure 16. TI model simulation SWE time series for the WY 2020.

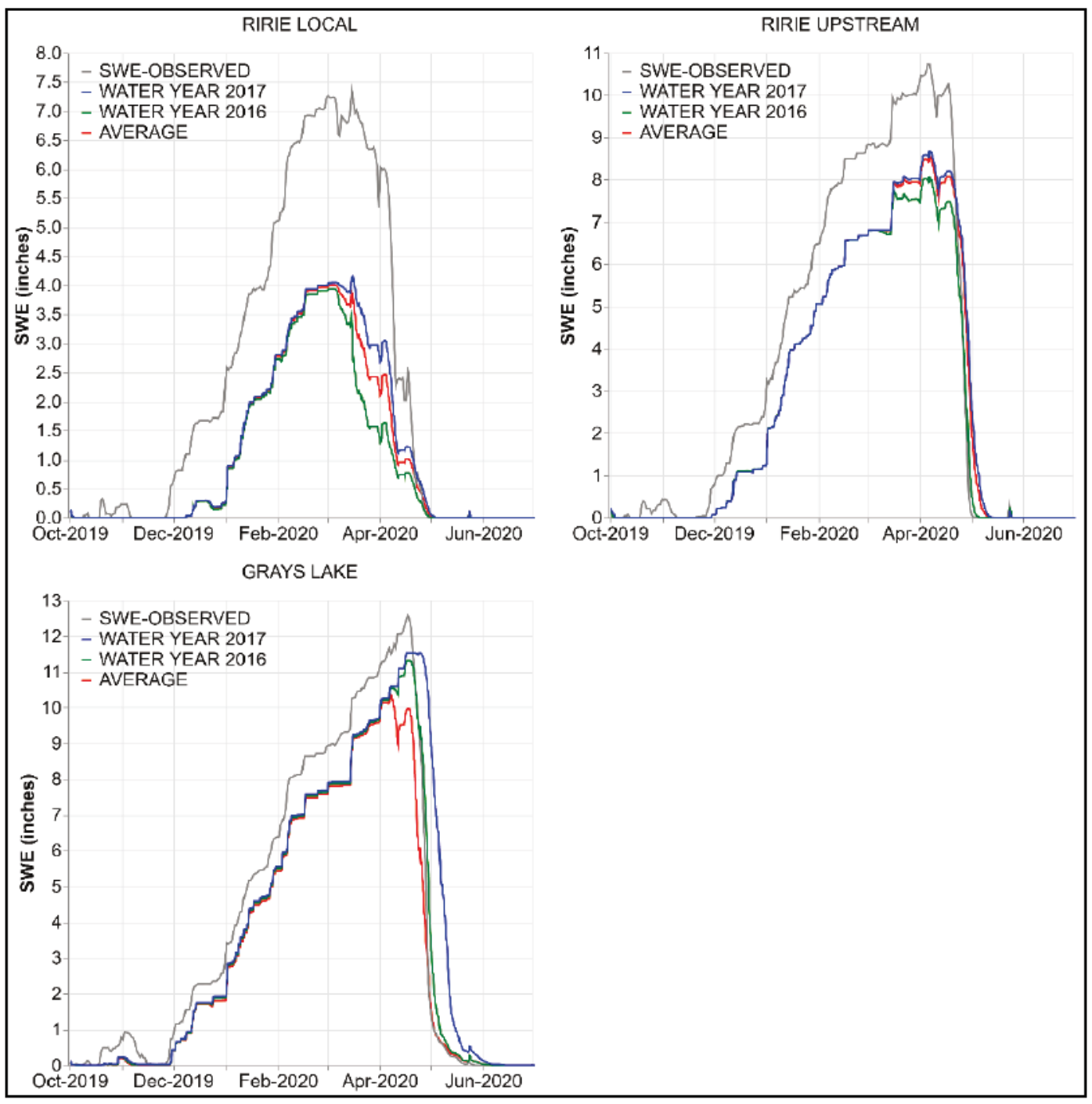


Table 8. TI simulation statistics for the WY 2020.

\begin{tabular}{|c|c|c|c|c|c|c|c|c|c|}
\hline \multirow{3}{*}{\begin{tabular}{l|} 
Simulation \\
Calibration \\
Subbasins
\end{tabular}} & \multicolumn{9}{|c|}{ WY 2020} \\
\hline & \multicolumn{3}{|c|}{ WY 16} & \multicolumn{3}{|c|}{ WY 17} & \multicolumn{3}{|c|}{ Average } \\
\hline & Ririe & $\begin{array}{l}\text { Ririe } \\
\text { Upstream }\end{array}$ & $\begin{array}{l}\text { Grays } \\
\text { Lake }\end{array}$ & Ririe & $\begin{array}{l}\text { Ririe } \\
\text { Upstream }\end{array}$ & $\begin{array}{l}\text { Grays } \\
\text { Lake }\end{array}$ & Ririe & $\begin{array}{l}\text { Ririe } \\
\text { Upstream }\end{array}$ & $\begin{array}{l}\text { Grays } \\
\text { Lake }\end{array}$ \\
\hline NSE & 0.438 & 0.884 & 0.961 & 0.601 & 0.892 & 0.863 & 0.543 & 0.894 & 0.941 \\
\hline Percent Bias & -58.17 & -26.08 & -12.64 & -50.02 & -21.14 & -3.83 & -55.35 & -22.27 & -18.18 \\
\hline RMSE & 0.75 & 0.34 & 0.2 & 0.63 & 0.33 & 0.37 & 0.68 & 0.33 & 0.24 \\
\hline Date Peak & $3 / 3 / 20$ & $4 / 6 / 20$ & $3 / 17 / 20$ & $3 / 15 / 20$ & $4 / 6 / 20$ & $4 / 24 / 20$ & $3 / 3 / 20$ & $4 / 6 / 20$ & $4 / 7 / 20$ \\
\hline $\begin{array}{l}\text { Observed } \\
\text { Peak Date }\end{array}$ & $3 / 15 / 20$ & $4 / 5 / 20$ & $4 / 17 / 20$ & $3 / 15 / 20$ & $4 / 5 / 20$ & $4 / 17 / 20$ & $3 / 15 / 20$ & $4 / 5 / 20$ & $4 / 17 / 20$ \\
\hline Peak SWE & 3.95 & 8.06 & 11.32 & 4.15 & 8.68 & 11.54 & 4.01 & 8.55 & 10.37 \\
\hline $\begin{array}{l}\text { Observed } \\
\text { Peak SWE }\end{array}$ & 7.37 & 10.74 & 12.59 & 7.37 & 10.74 & 12.59 & 7.37 & 10.74 & 12.59 \\
\hline
\end{tabular}




\section{Radiative Temperature Index (RTI) Model}

The RTI model implementation is based on the temperature index model SNOW 17 (Anderson 2006) and radiative temperature described by Follum et al. (2015). The units for the formulation of the SNOW 17 temperature index are not presented to avoid confusion with the TI model but are assumed to follow the units described in Anderson (2006). The majority of the formulation assumes a metric unit system, with the exception of some of the empirical relationships used to calculate outflow from the snowpack. The model description provided here is a synthesis of the reference literature. While we attempted to combine this information in this report, how closely the RTI implementation in HEC-HMS 4.7 follows this formulation will require future work.

\subsection{Snowpack accumulation}

The snow accumulation process on the land surface in the RTI model is similar to the TI model in HEC-HMS, where the phase of precipitation inputs is referenced to an air temperature threshold. The primary difference between the RTI and TI models is the RTI model has a threephase snowpack consisting of ice, SWE, and water components. The model is parameterized with two air temperature thresholds that dictate what proportion of the precipitation is liquid rain $\left(T_{p x, \text { rain }}\right)$ or solid snow $\left(T_{p x \text {,snow }}\right)$. When $T_{p x \text {,rain }}>T_{p x, \text { snow }}$ the new precipitation is divided into rain and snow components when the current air temperature is between the two thresholds.

\subsection{Snowpack temperature}

The process of tracking energy exchanges within a snowpack is through a function of heat deficit $(D)$ (Equation 5).

$$
D_{2}=D_{1}+\Delta D_{t}+\Delta D_{p}
$$

The heat deficit budget is an accumulation of the deficit from the previous time-step $D_{1}$, the deficits associated with air temperature $\left(\Delta D_{t}\right)$ and liquid precipitation $\left(\Delta D_{p}\right)$. The heat deficit fluctuations are related to air temperature $\left(\Delta D_{t}\right.$, Equation 6) and are a function of a negative melt factor $N M F$, an accumulated temperature index (ATI) and snow surface temperature $\left(T_{\text {sur }}\right)$. 


$$
\Delta D_{t}=N M F *\left(A T I-T_{\text {sur }}\right)
$$

In this model, $T_{\text {sur }}$ is assumed to be $0{ }^{\circ} \mathrm{C}$ when $T_{a}$ is above freezing or $T_{a}$ when it is less than freezing. $N M F$ (Equation 6) is used to account for increases in thermal conductivity associated with the density evolution of the snowpack (Melloh 1999).

$$
N M F=N M F_{\text {max }}(d t / 6)\left(M_{f, t} / M_{f, \max }\right)
$$

Where $N M F_{\text {max }}$ is the maximum negative melt factor, $\mathrm{dt}$ is the time-step of the input temperature input data, $M_{f, t}$ is the melt factor for the current time-step, and $M_{f, \max }$ is the maximum melt factor. As $M_{f, t}$ approaches the value of $M_{f, \max }$, the thermal conductivity will allow for larger deficit fluctuations. The formulation of the RTI model parameter ATI (Equation 8 ) is similar to the formulation of ATICC (Equation 1) in the TI model. The difference between formulations is the hybrid TI model scales the nondimensional TIPM coefficient using a native time-step of $6 \mathrm{hr}$.

$$
A T I_{2}=A T I_{1}+\left(1-\left(1-T I P M_{2}\right)^{1 / 6}\right)\left(T_{a}-A T I_{1}\right)
$$

Heat deficits will increase when ATI is greater than $T_{\text {sur }}$ and decrease when ATI is zero. The heat deficit budget is increased by the amount of heat required to bring the new $\mathrm{SWE}$ accumulation to $\mathrm{O}^{\circ} \mathrm{C}$. The changes in heat deficit associated with new snow accumulations are calculated using Equation 9.

$$
\Delta D_{p}=-\frac{P_{n} T_{\text {snow }} c_{i}}{L_{f}}
$$

where $P_{n}$ is new SWE accumulations, $T_{\text {snow }}$ is the temperature of the new $\mathrm{SWE}, c_{i}$ is the specific heat of ice, $L_{f}$ is the latent heat of fusion of water. $T_{\text {snow }}$ is assumed to be $\mathrm{o}^{\circ} \mathrm{C}$ when $T_{a}$ is above freezing or the value of $T_{a}$ when it is less than freezing.

\subsection{Surface melt}

In the TI model implemented in SNOW 17 (Anderson 2006), dry melt ( $M$ ) is calculated using Equation 10.

$$
M=\left[M_{f} * T_{a}+0.0125 * P * f_{r} * T_{r}\right] d t
$$


where $f_{r}$ is the fraction of precipitation as rain, $T_{r}$ is the precipitation temperature (usually approximated by the air temperature), $M_{f}$ is a melt factor, and $P$ is precipitation. A wet melt rate is calculated using Equation 11 (Anderson 2006) when precipitation inputs exceed $1.5 \mathrm{~mm} / \mathrm{hr}$.

$$
\begin{aligned}
M= & \sigma * d t\left[\left(T_{a}+273\right)-273^{4}\right]+0.0125 * P * f_{r} * T_{r}+ \\
& 8.5 * f_{u} *(d t / 6) *\left[\left(r h * e_{s a t}-6.11\right)+0.00057 * P_{a} * T_{a}\right]
\end{aligned}
$$

where $\sigma$ is the Stefan-Boltzmann constant, $f_{u}$ is a wind function, $r h$ is the relative humidity, $e_{s a t}$ is the saturation vapor pressure, and $P_{a}$ is atmospheric pressure.

\subsection{Runoff model}

The snowpack in the RTI model evolves over multiple time-steps using empirical relationships that account for water moving through a snowpack with frozen water. First, a heat budget approach is used to determine if the new surface melt can overcome the liquid water holding capacity and heat deficits from the previous time-step. Second, excess water is routed through the snowpack using empirical relationships that estimate travel time and withdrawal rates. Finally, the melt is released as outflow that accounts for storage and lagged water from previous time-steps. These steps are depicted in Figure 18 and described in the subsection following. The physical interpretations of the variables in Figure 17 are defined in Table 9. 
Figure 17. Flow chart summarizing the RTI runoff model.

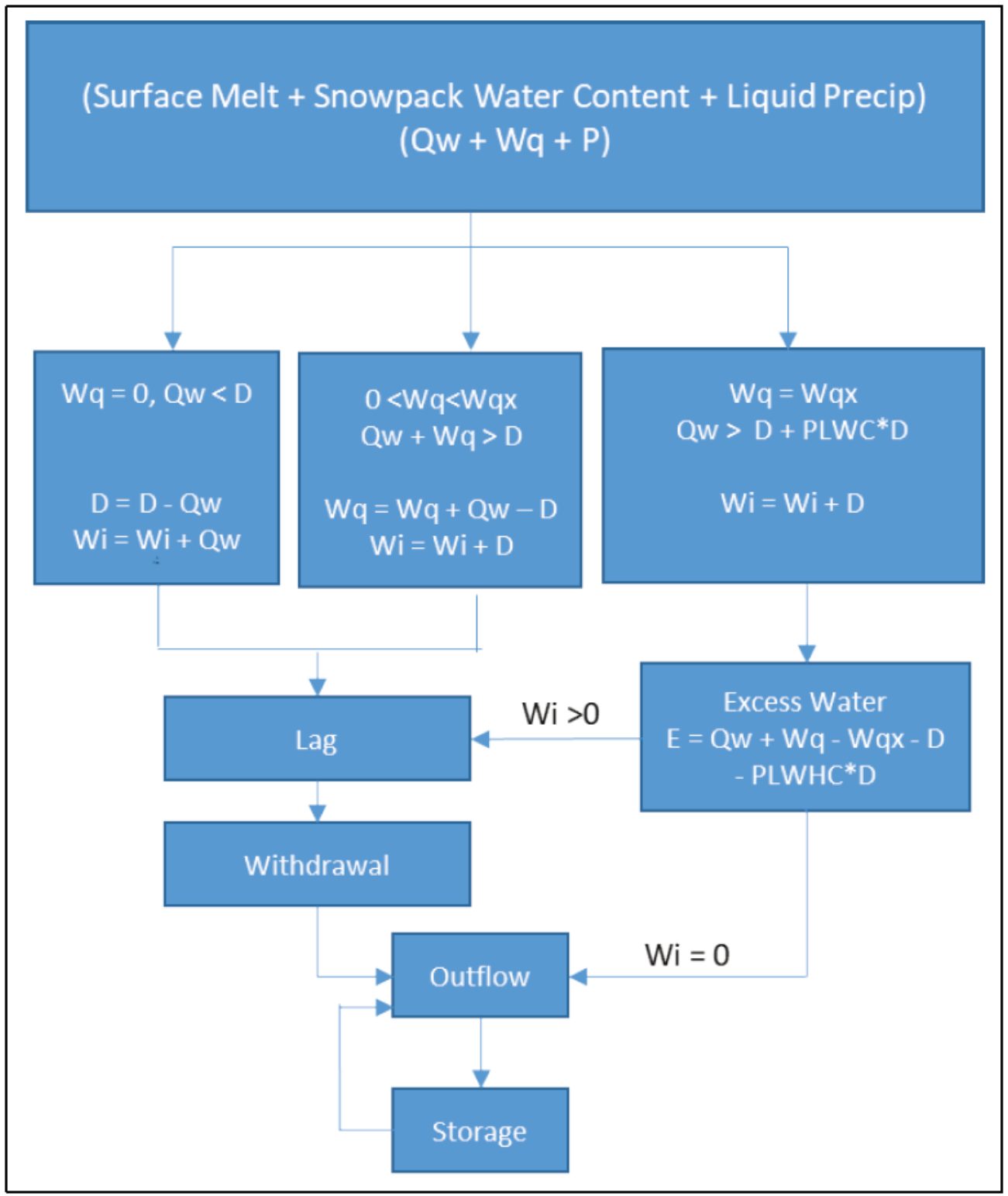

Table 9. RTI model runoff parameter descriptions for variables in Figure 18.

\begin{tabular}{|l|l|}
\hline Parameter & Physical Description \\
\hline D & Heat Deficit \\
\hline Qw & Surface Melt \\
\hline Wq & Liquid water in snowpack \\
\hline Wi & Amount of Ice in Snow \\
\hline PLWHC & Maximum Liquid Water Capacity \\
\hline Wqx & Liquid Water Capacity \\
\hline
\end{tabular}




\subsubsection{Heat budget updating}

The rate of water being released from the bottom of a snowpack is modeled using a percolation algorithm that depends on the overall heat deficit of the snowpack. First, the heat deficit budget is used to determine if the snowpack is ripe (e.g., exceeded maximum liquid water holding capacity), partially ripe, or too cold to ripen. The excess water ( $E$, Equation 12) available to percolate through a snowpack is produced when the available liquid water on the snow surface $\left(Q_{w}\right)$ and the liquid water inside the snowpack $\left(W_{q}\right)$ can fill the liquid water holding capacity of the snowpack $\left(W_{q x}\right)$, melt ice layers associated with previous melting events $\left(W_{q x}\right)$, reduce the overall heat deficit $(D)$ to zero, and overcome the heat deficit associated with the increased holding capacity of a well-aged snowpack $(P L W H C * D)$.

$$
E=Q_{w}+W_{q}-W_{q x}-D-P L W H C * D
$$

where $P L W H C$ is the percent liquid water holding capacity (assumed to be o.4). If excess water is not formed, the heat budget is used to modify the internal ice and water layers in the snowpack. If there is enough melted water $\left(Q_{w}\right)$ to satisfy the heat deficit, but not overcome the liquid water holding capacity of the snowpack, the amount of available liquid water is calculated using Equation 13.

$$
W_{q}=W_{q}+Q_{w}-D
$$

When conditions for Equation 12 exist, the amount of snow and ice $\left(W_{i}\right)$ in the snowpack is increased by the heat deficit because water will refreeze (Equation 14).

$$
W_{i}=W_{i}+D
$$

If the amount of melted water on the surface $\left(Q_{w}\right)$ is not able to satisfy the heat deficit, the heat deficit is reduced by the amount of available water (Equation 15).

$$
D=D-Q_{w}
$$

Additionally, the amount of snow and ice in the snowpack is also increased by the amount of available water that refroze (Equation 16).

$$
W_{i}=W_{i}+Q_{w}
$$




\subsubsection{Snowpack routing}

When there is excess water that can move through a snowpack, the model uses a lag $(L)$ parameter to describe how long it will take for the excess water to reach the bottom of the snowpack (Equation 17) (Hildebrand and Pagenheart 1955 ).

$$
L=5.33\left[1-e^{\left(-0.03\left(\frac{d t}{6}\right) W_{i} / E\right.}\right]
$$

The attenuated portion of the excess water $(E)$ is removed from a snowpack using a withdrawal rate ( $R$, Equation 18).

$$
R=\frac{1}{1+5 e^{\frac{\left(-500 E_{l s}\right)^{1.3}}{W_{i s}}}}
$$

where $W_{i s}$ is the mean water equivalent of the ice portion of the snow over the snow-covered area $\left(A_{s}\right)$ (Equation 19).

$$
W_{i s}=\frac{W_{i}}{25.4 A_{s}}
$$

and $E_{l s}$ is the average hourly lagged excess liquid water available for the current time-step relative to the snow-covered area $\left(A_{s}\right)$ (Equation 20).

$$
E_{l s}=\frac{E_{1}}{25.4 A_{s}}
$$

where $E_{1}$ is the average hourly lagged excess water available in the current time-step.

\subsection{Outflow}

Using the calculated withdrawal rate ( $R$, Equation 17) and hourly snow cover, outflow $\left(O_{m, r}\right)$ from surface melt or rain can be calculated using Equation 21.

$$
O_{m, r 1}=\left(S_{1}+E_{1}\right) R_{1}
$$

where $S_{1}$ is the amount of lagged excess water in storage at the beginning of the time-step. The amount of lagged excess liquid water in storage at the end of the hour $\left(S_{2}\right)$ can be calculated using Equation 22. 


$$
S_{2}=\left(S_{1}+E_{1}\right)-O_{m, r 1}
$$

When there is no lagged excess water stored in the snowpack, $S_{1}$ in Equation 20 and Equation 21 is set to zero.

\subsection{Radiative temperature}

The formulation for the RTI model is complete when $T_{a}$ in Equation 9 and Equation 10 is substituted with radiative temperature ( $T_{\text {rad }}$, Equation 23) (Follum et al. 2015) that is calculated using a simplified solar radiation budget.

$$
T_{\text {rad }}=\left[\frac{L W_{\downarrow}-S W_{\downarrow, n e t}}{\varepsilon_{\text {snow }} \sigma}\right]^{1 / 4}-273.15
$$

where $L W_{\downarrow}$ is the downwelling longwave radiation, $S W_{\downarrow, \text { net }}$ is the net shortwave radiation at the snow surface, $\varepsilon_{\text {snow }}$ is the emissivity of snow, and $\sigma$ is the Stefan-Boltzmann constant. The downwelling longwave radiation is calculated using Equation 24.

$L W_{\downarrow}=\left[\sigma\left(T_{a}+273.15\right)^{4}\left(1+0.17 N^{2}\right)\right]\left(1-F_{c}\right)+F_{c} \varepsilon_{c} \sigma\left(T_{c}+273.15\right)^{4}$

where $N$ is the fractional cloud cover, $F_{c}$ is the fractional canopy cover, $\varepsilon_{c}$ is the canopy emissivity, and $T_{c}$ is the canopy temperature. The net downwelling shortwave radiation is calculated using Equation 25.

$$
S W_{\downarrow, \text { net }}=\left(S_{0} K_{r} K_{a t m} K_{c} K_{v} K_{s} K_{t}\right)(1-\alpha)
$$

where $S_{0}$ is the solar constant, $\alpha$ is snow albedo, and the $K$ reduction factors in short wave radiation from distance from the sun to Earth $(r)$, atmospheric scattering $(\mathrm{atm})$, absorption from clouds $(\mathrm{c})$, vegetation $(v)$, slope/aspect of terrain ( $s$ ), and topographic shading $(t) . K_{r}$ is calculated using a trigonometric relationship that describes how the distance between the earth and sun varies seasonally (Equation 26).

$$
K_{r}=\left[1+0017 \cos \left(\frac{2 \pi}{365}(1-J D)\right)\right]^{-2}
$$

where JD is a Julian day. $K_{a t m}$ is calculated as a function of model terrain elevation (Equation 27). 


$$
K_{\text {atm }}=0.75+\left(2 \cdot 10^{-5}\right) \text { Elev }_{c}
$$

where $E l e v_{c}$ represents the elevation of the raster cell. The reduction factor associated with clouds $K_{c}$ is calculated using Equation 28.

$$
K_{c}=1.0-0.65 N^{2}
$$

The reduction factor related to slope and aspect of the model terrain $K_{S}$ is calculated using Equation 29.

$$
K_{s}=\cos (\varphi)
$$

where $\varphi$ is the angle of incidence between the incoming solar radiation and the ground surface. Finally, the albedo $\left(\alpha_{t}\right)$ of the snowpack is calculated as a function of days $(d)$ since the last snow accumulation (Equation 30).

$$
\alpha_{t}=0.83-0.011 d
$$

When melting, $\alpha_{t}$ is calculated using Equation 31.

$$
\alpha_{t}=\alpha_{t-1}-\mathrm{w}
$$

where $w$ is 0.17 when the daily average temperature is above $0^{\circ} \mathrm{C}$ and 0.013 when the daily average temperature is below $0^{\circ} \mathrm{C}$.

\subsection{Current HMS Implementation}

In the current HMS implantation of the hybrid temperature index model, some simplifications are made to reduce the data requirements for the model. The simplifications presented in the following subsections are based on a direct review of the RTI model in HEC-HMS 4.7 beta.

The current default inputs for the RTI model are the following:

- Air Temperature $\left(T_{a}\right)$ - Temperature grids

- Rain Threshold $-37.4^{\circ} \mathrm{F}$

- Snow Threshold $-30.2^{\circ} \mathrm{F}$

- Base Temperature $\left(T_{b}\right)-32^{\circ} \mathrm{C}$

- Melt Factor $\left(M_{f}\right)-0.007222$ in. $/{ }^{\circ} \mathrm{F}-6 \mathrm{hr}$

- Max Negative Melt Factor $\left(N M F_{\max }\right)-0.011$ in. $/{ }^{\circ} \mathrm{F}-6 \mathrm{hr}$ 
- $\quad$ ATI Coefficient - 0.8

- Wind Function - 0.667

- Water capacity $-\mathbf{2 . 0} \%$.

\subsubsection{Negative melt factor}

The maximum melt factor $\left(M_{f, \max }\right)$ is not specified in the current model. In the implementation in HEC-HMS, the ratio of melt factors in Equation 7 is approximated by the ratio of daily maximum to annual maximum downwelling short wave radiation (Equation 32).

$$
S W_{\downarrow, n m f}=S_{0} K_{r} K_{a t m} K_{s}
$$

\subsubsection{Dry melt}

The fraction of precipitation that is in liquid form $\left(f_{r}\right)$ is not specified. This fraction could be calculated using the snow and rain temperature thresholds, but further investigation is required as to how the model accounts for mixed-phase precipitation in the snowpack. In this study, we kept the snow and rain threshold equal, which effectively reduces $f_{r}$ to a binary variable that can be $0 \%$ or $100 \%$ rain.

\subsubsection{Wet melt}

The wind function $\left(f_{u}\right)$ is not currently used in the wet melt rate calculations and has been hardcoded to 1.0 to not influence the melt calculations. This parameter is used to describe the stability of the atmosphere at the land surface and is most important when exchanges of latent and sensible heat are the main components for energy to melt snow.

The relative humidity is assumed to be $90 \%$ during welt melt events.

The saturation vapor pressure $\left(e_{\text {sat }}\right)$ is approximated using the ClausiusClapeyron equation.

The atmospheric pressure $\left(P_{a}\right)$ is approximated using a standard atmospheric altitude versus pressure relationship (Anderson 2006, Equation A-9). 


\subsubsection{Downwelling long wave radiation}

In the current implementation, the parameters related to cloud coverage and canopy are not specified. The fractional canopy cover is assumed to be o.o, and fraction cloud coverage is assumed to be 0.5. The canopy air temperature $\left(T_{c}\right)$ is assumed to be equal to the air temperature $\left(T_{a}\right)$. For Willow Creek, assuming a fractional canopy cover of o.o seems reasonable for the majority of the watershed. That assumption would not be valid in the "tree islands" that exist near the SNOTEL locations (Giovando et al. 2020).

\subsubsection{Net downwelling shortwave radiation}

In the current implementation, the cloud and vegetation parameters are not specified. The reduction factors $K_{c}$ and $K_{v}$ are both assumed to be 1.o.

\subsection{RTI model calibration}

WYs 2016 and 2017 were used to calibrate the RTI snowmelt model to the UA SWE time series. In the current implementation in HMS, the gridded hybrid meteorological model applies a single parameterization for the Willow Creek. The calibration focused on maximizing model performance in the Ririe Upstream subbasin. The resulting model calibration parameters for WYs 2016 and 2017 are shown in Table 10.

Table 10. Calibrated RTI parameters for WYs 2016, 2017, and calculated average.

\begin{tabular}{|l|l|l|l|}
\hline & WY16 & WY17 & Average \\
\hline Rain threshold $\left({ }^{\circ} \mathrm{F}\right)$ & 34 & 35 & 34.5 \\
\hline Snow Threshold $\left({ }^{\circ} \mathrm{F}\right)$ & 34 & 35 & 34.5 \\
\hline Base Temperature $\left({ }^{\circ} \mathrm{F}\right)$ & 32 & 32 & 32 \\
\hline Melt Factor $\left(\right.$ in $\left./{ }^{\circ} \mathrm{F}\right)$ & 0.00722 & 0.01 & 0.00861 \\
\hline Max Negative Melt Factor $\left(\right.$ in $\left./{ }^{\circ} \mathrm{F}\right)$ & 0.011 & 0.031 & 0.021 \\
\hline ATI Coefficient & 0.85 & 0.85 & 0.85 \\
\hline Water Capacity $(\%)$ & 2 & 2 & 2 \\
\hline
\end{tabular}


The model parameters maximum negative melt factor and melt factor had the most variation between the two calibration years. Both calibrations required relatively high snow thresholds to best match the magnitude of the observed peak SWE.

The simulated SWE time series for the WY 2016 is shown in Figure 18 and summarized in Table 11. For Ririe Upstream, the model had a slight (low) negative bias and low RMSE. The timing and magnitude of peak SWE, relative to the UA data, were overestimated by 1.5 days and underpredicted the magnitude of peak SWE by 0.59 in., respectively.

Figure 18. RTI snowmelt calibration for the WY 2016.

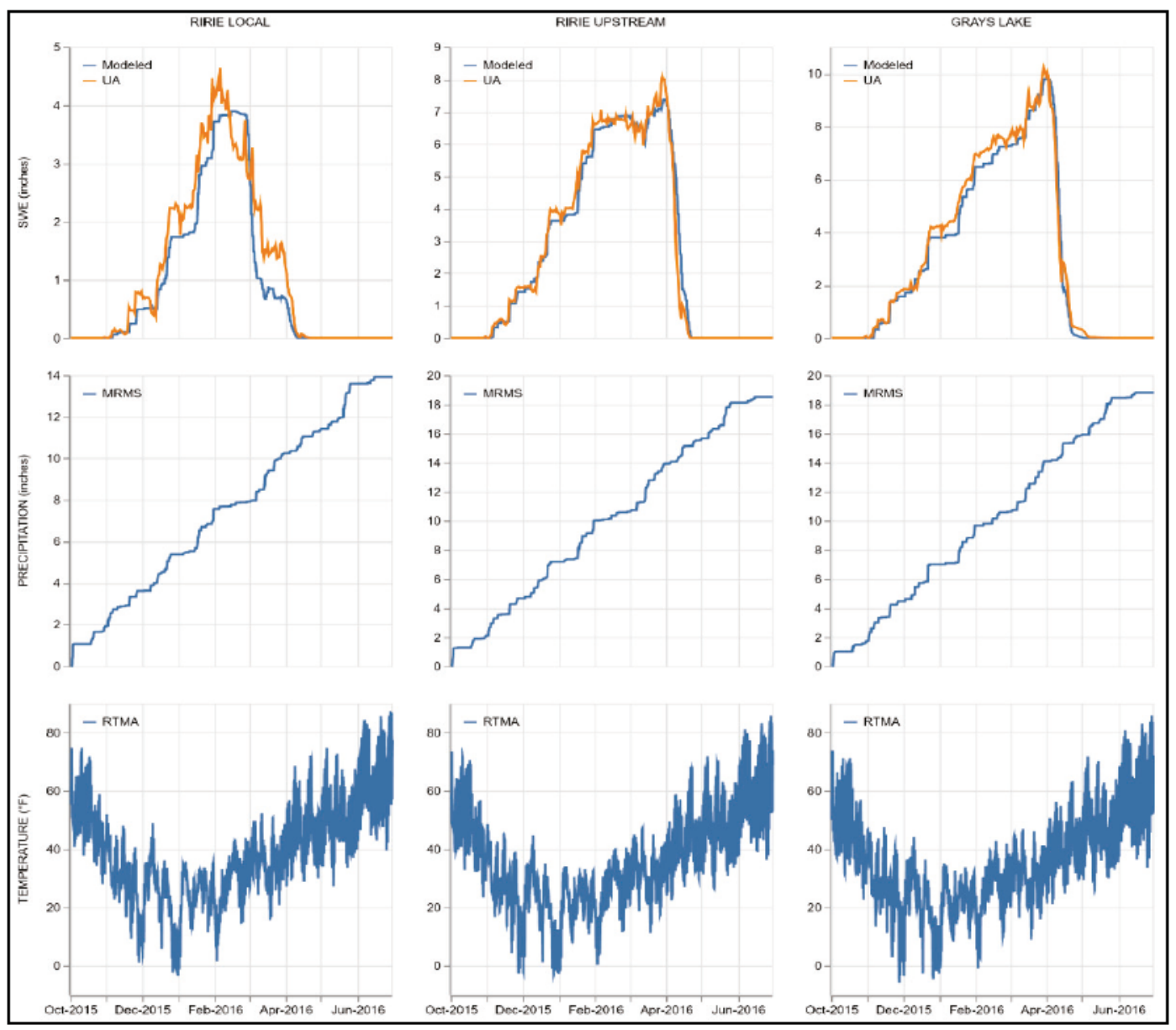

The simulated SWE time series for the WY 2017 is shown in Figure 19 and summarized in Table 11. For Ririe Upstream, the model had a slight (low) negative bias and low RMSE. The timing and magnitude of peak SWE, relative to the UA data, were overestimated by 13 days and underpredicted the magnitude of peak SWE by 1.2 in., respectively. The discrepancy in the 
timing of peak SWE is created by a suspicious spike in the UA-observed data that was followed by a period of accumulation that almost reached the same magnitude of the spike.

Figure 19. RTI snowmelt calibration for the WY 2017.

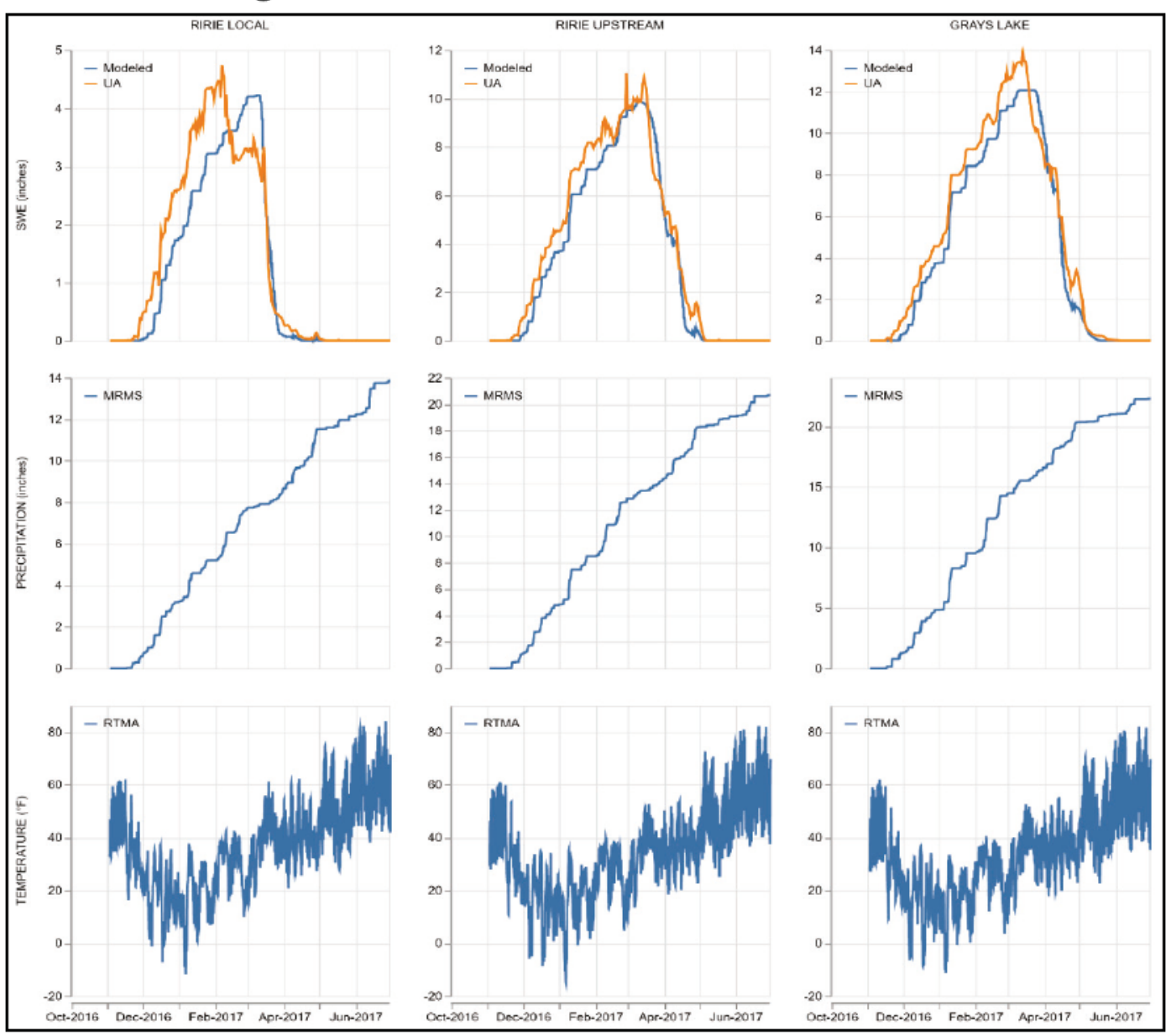

Table 11. RTI snowmelt model calibration statistics.

\begin{tabular}{|l|l|l|l|l|l|l|}
\hline & \multicolumn{3}{|c|}{ WY 2016 } & \multicolumn{3}{c|}{ WY 2017 } \\
\hline & Ririe & Ririe Upstream & Grays Lake & Ririe & Ririe Upstream & Grays Lake \\
\hline NSE & 0.905 & 0.983 & 0.987 & 0.860 & 0.963 & 0.963 \\
\hline Percent Bias & -17.25 & -0.72 & -5.26 & -14.51 & -10.80 & -11.14 \\
\hline RMSE & 0.31 & 0.13 & 0.12 & 0.37 & 0.19 & 0.19 \\
\hline Date Peak & $2 / 14 / 16$ & $3 / 30 / 16$ & $3 / 30 / 16$ & $3 / 8 / 17$ & $3 / 10 / 17$ & $3 / 23 / 17$ \\
\hline Observed Peak Date & $2 / 5 / 16$ & $3 / 28 / 16$ & $3 / 29 / 16$ & $2 / 6 / 17$ & $2 / 27 / 17$ & $3 / 13 / 17$ \\
\hline Peak SWE & 3.89 & 7.4 & 9.8 & 4.22 & 9.88 & 12.07 \\
\hline Observed Peak SWE & 4.65 & 8.09 & 10.22 & 4.75 & 11.06 & 13.81 \\
\hline
\end{tabular}




\subsection{RTI model validation}

WYs 2018-2020 were simulated using the three calibration parameter sets described in Table 8. The simulated SWE time series for the WY 2018 is shown in Figure 20 and summarized in Table 12. There are differences between the parameter sets in the timing and magnitude of peak SWE. For Ririe Upstream, the highest NSE value of the 2018 validation simulations was using the 2017 calibration parameters. These parameters also produced the lowest RMSE along with a slight negative (low) bias in the peak SWE value.

Figure 20. RTI simulated SWE time series for the WY 2018.

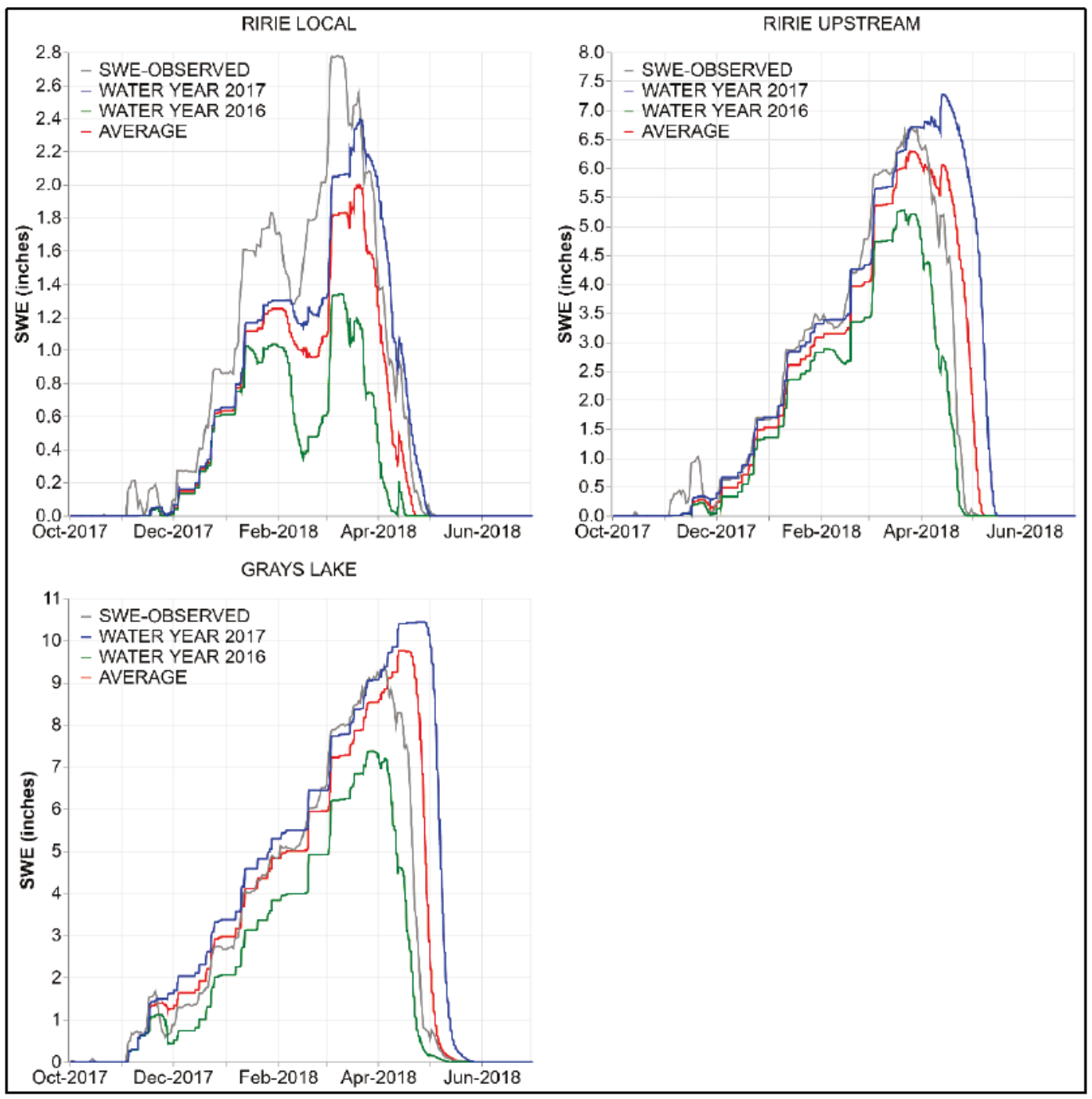


Table 12. RTI simulation WY 2018 summary statistics.

\begin{tabular}{|c|c|c|c|c|c|c|c|c|c|}
\hline \multirow{3}{*}{$\begin{array}{l}\text { Simulation } \\
\text { Calibration } \\
\text { Subbasins }\end{array}$} & \multicolumn{9}{|c|}{ WY 2018} \\
\hline & \multicolumn{3}{|c|}{ WY 16} & \multicolumn{3}{|c|}{ WY 17} & \multicolumn{3}{|c|}{ Average } \\
\hline & Ririe & $\begin{array}{l}\text { Ririe } \\
\text { Upstream }\end{array}$ & $\begin{array}{l}\text { Grays } \\
\text { Lake }\end{array}$ & Ririe & $\begin{array}{l}\text { Ririe } \\
\text { Upstream }\end{array}$ & $\begin{array}{l}\text { Grays } \\
\text { Lake }\end{array}$ & Ririe & \begin{tabular}{|l} 
Ririe \\
Upstream
\end{tabular} & $\begin{array}{l}\text { Grays } \\
\text { Lake }\end{array}$ \\
\hline NSE & 0.434 & 0.865 & 0.852 & 0.884 & 0.597 & 0.534 & 0.813 & 0.892 & 0.875 \\
\hline $\begin{array}{l}\text { Percent } \\
\text { Bias }\end{array}$ & -56.34 & -27.69 & -27.55 & -16.16 & 20.82 & 27.52 & -32.78 & -0.04 & 6.96 \\
\hline RMSE & 0.75 & 0.37 & 0.38 & 0.34 & 0.64 & 0.68 & 0.43 & 0.33 & 0.35 \\
\hline Date Peak & $3 / 9 / 18$ & $3 / 21 / 18$ & $3 / 28 / 18$ & $3 / 21 / 18$ & $4 / 13 / 18$ & $4 / 23 / 18$ & $3 / 21 / 18$ & $3 / 25 / 18$ & $4 / 14 / 18$ \\
\hline $\begin{array}{l}\text { Observed } \\
\text { Peak Date }\end{array}$ & $3 / 7 / 18$ & $3 / 26 / 18$ & $4 / 4 / 18$ & $3 / 7 / 18$ & $3 / 26 / 18$ & $4 / 4 / 18$ & $3 / 7 / 18$ & $3 / 26 / 18$ & $4 / 4 / 18$ \\
\hline Peak SWE & 1.34 & 5.27 & 7.37 & 2.40 & 7.27 & 10.43 & 2.00 & 6.29 & 9.76 \\
\hline $\begin{array}{l}\text { Observed } \\
\text { Peak SWE }\end{array}$ & 2.78 & 6.70 & 9.39 & 2.78 & 6.70 & 9.39 & 2.78 & 6.7 & 9.39 \\
\hline
\end{tabular}

The simulated SWE time series for the WY 2019 is shown in Figure 21 and summarized in Table 13. There was minimal sensitivity to parameter selection during the simulated accumulation period before peak SWE. For Ririe Upstream, the highest NSE value of the 2019 validation simulations was using the 2016 calibration parameters. These parameters also produced the lowest RMSE along with a negative (low) bias in the peak SWE value. The 2016 and 2017 parameters had a period of minimal SWE accumulation before the melting of the spring runoff began. While the calibration did not focus on Grays Lake, the WY 2017 parameters resulted in a more defined period of minimal accumulations before melting of the spring runoff began. 
Figure 21. RTI simulated SWE time series for the WY 2019.

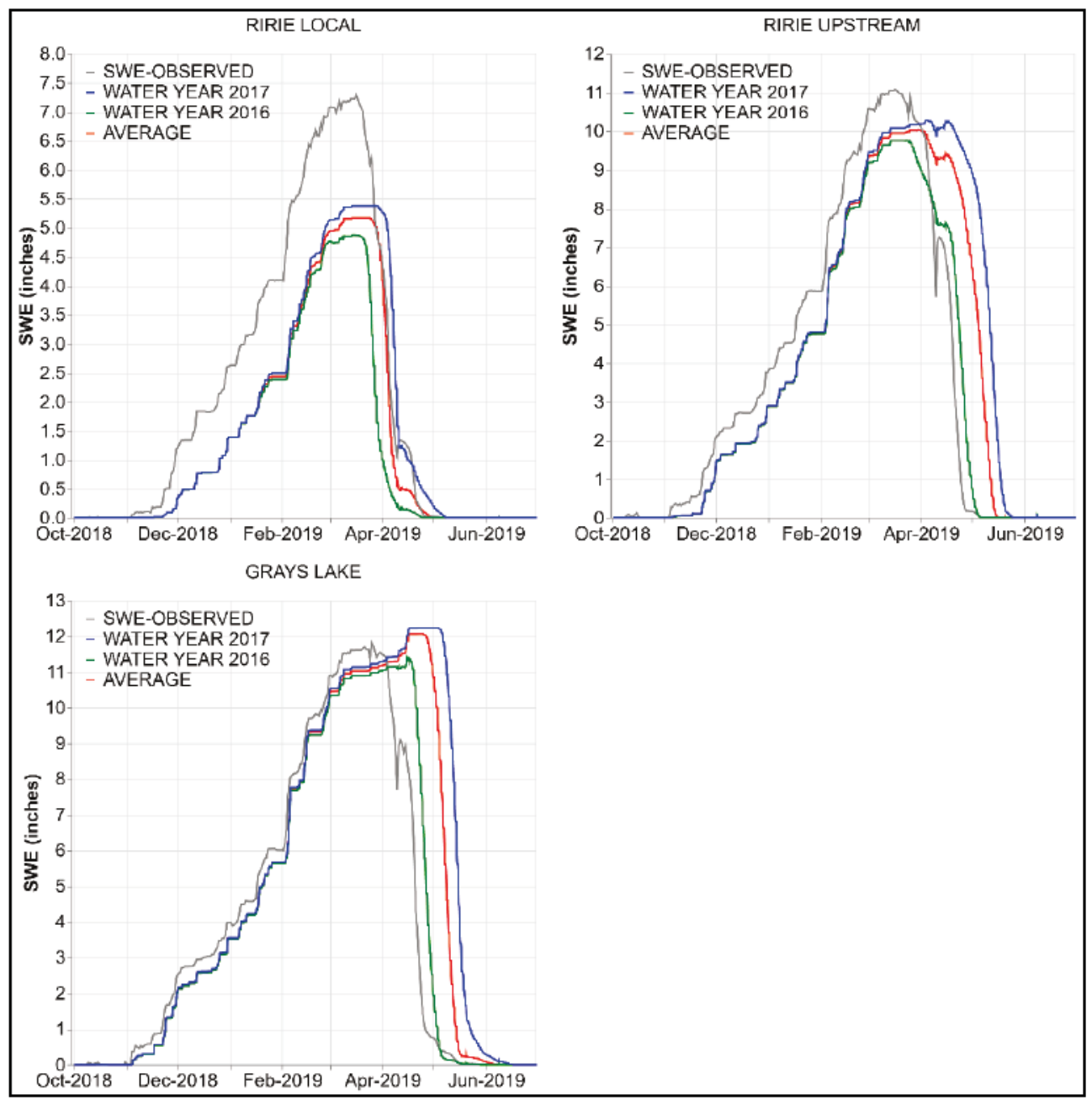

Table 13. RTI simulation WY 2019 summary statistics.

\begin{tabular}{|c|c|c|c|c|c|c|c|c|c|}
\hline Simulation & & & & & WY 2019 & & & & \\
\hline Calibration & & WY 16 & & & WY 17 & & & Average & \\
\hline Subbasins & Ririe & $\begin{array}{l}\text { Ririe } \\
\text { Upstream }\end{array}$ & $\begin{array}{l}\text { Grays } \\
\text { Lake }\end{array}$ & Ririe & $\begin{array}{l}\text { Ririe } \\
\text { Upstream }\end{array}$ & $\begin{array}{l}\text { Grays } \\
\text { Lake }\end{array}$ & Ririe & $\begin{array}{l}\text { Ririe } \\
\text { Upstream }\end{array}$ & $\begin{array}{l}\text { Grays } \\
\text { Lake }\end{array}$ \\
\hline NSE & 0.711 & 0.937 & 0.918 & 0.814 & 0.592 & 0.388 & 0.792 & 0.839 & 0.725 \\
\hline $\begin{array}{l}\text { Percent } \\
\text { Bias }\end{array}$ & -44.30 & -11.46 & 0.82 & -28.58 & 11.18 & 24.63 & -37.93 & -1.62 & 10.72 \\
\hline RMSE & 0.54 & 0.25 & 0.29 & 0.43 & 0.64 & 0.78 & 0.46 & 0.40 & 0.52 \\
\hline Date Peak & $3 / 14 / 19$ & $3 / 23 / 19$ & $4 / 16 / 19$ & $3 / 25 / 19$ & $4 / 4 / 19$ & $5 / 2 / 19$ & $3 / 14 / 19$ & $3 / 25 / 19$ & $4 / 7 / 19$ \\
\hline $\begin{array}{l}\text { Observed } \\
\text { Peak Date }\end{array}$ & $3 / 16 / 19$ & $3 / 16 / 19$ & $3 / 25 / 19$ & $3 / 16 / 19$ & $3 / 16 / 19$ & $3 / 25 / 19$ & $3 / 16 / 19$ & $3 / 16 / 19$ & $3 / 25 / 19$ \\
\hline Peak SWE & 4.87 & 9.76 & 11.4 & 5.38 & 10.28 & 12.24 & 5.17 & 10.02 & 12.06 \\
\hline $\begin{array}{l}\text { Observed } \\
\text { Peak SWE }\end{array}$ & 7.29 & 11.09 & 11.83 & 7.29 & 11.09 & 11.83 & 7.29 & 11.09 & 11.83 \\
\hline
\end{tabular}


The simulated SWE time series for the WY 2020 is shown in Figure 22 and summarized in Table 14. There was minimal sensitivity to parameters selection during the simulated accumulation period before peak SWE. For Ririe Upstream, the primary differences are in duration and magnitude of peak SWE. The WY 2017 and average parameters had similar NSE, RMSE, and negative (low) bias of peak SWE. The WY 2017 parameters had the largest amount of SWE accumulation but was still more than 2 in. less than the UA data. The negative (low) bias is likely because the MRMS data were normalized to early release and provisional data.

Figure 22. RTI simulated SWE time series for the WY 2020.

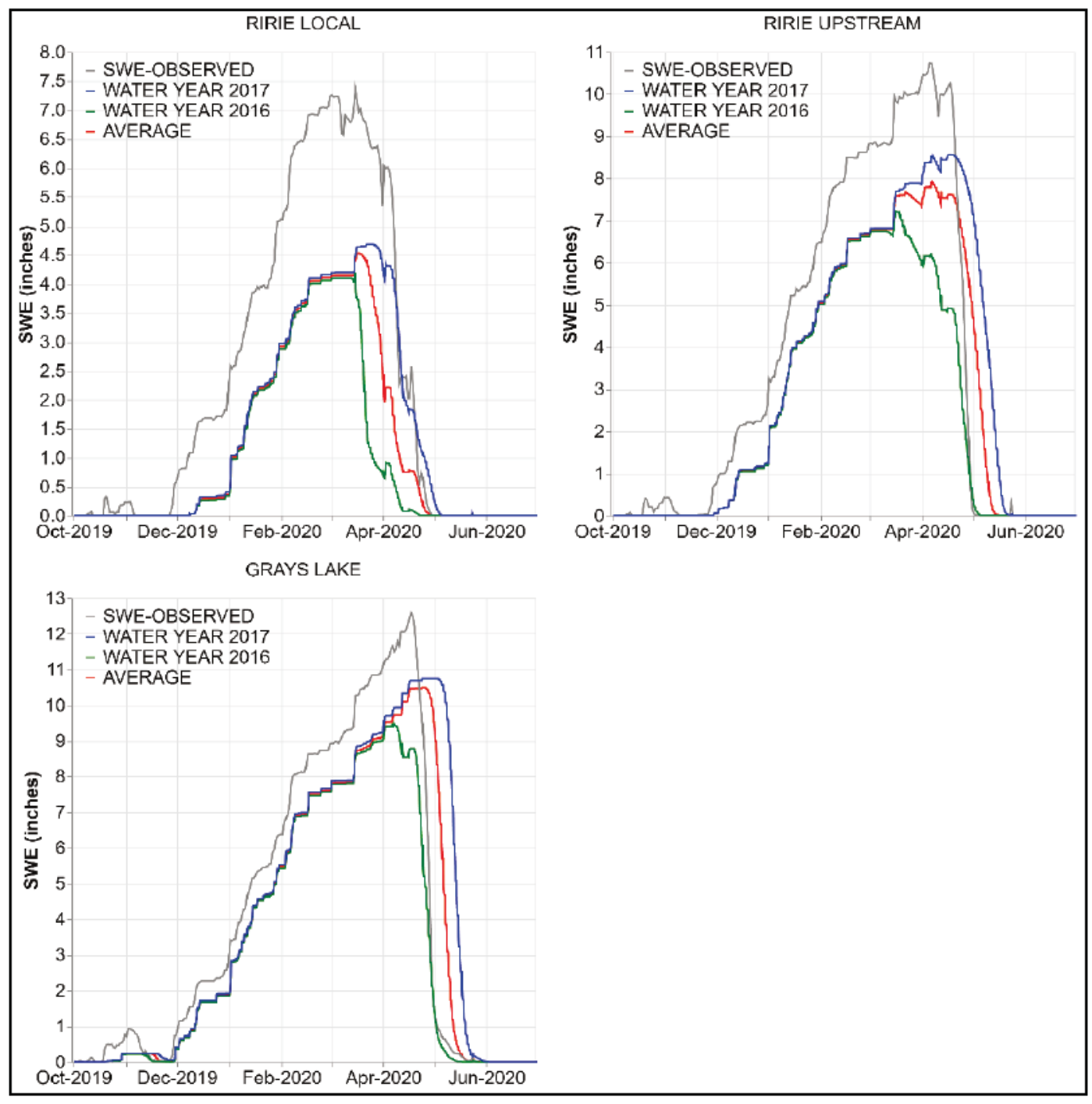


Table 14. RTI simulation WY 2020 statistics.

\begin{tabular}{|c|c|c|c|c|c|c|c|c|c|}
\hline $\begin{array}{l}\text { Simulation } \\
\text { Year }\end{array}$ & \multicolumn{9}{|c|}{ WY 2020} \\
\hline Calibration & \multicolumn{3}{|c|}{ WY 16} & \multicolumn{3}{|c|}{ WY 17} & \multicolumn{3}{|c|}{ Average } \\
\hline Subbasins & Ririe & $\begin{array}{l}\text { Ririe } \\
\text { Upstream }\end{array}$ & $\begin{array}{l}\text { Grays } \\
\text { Lake }\end{array}$ & Ririe & $\begin{array}{l}\text { Ririe } \\
\text { Upstream }\end{array}$ & $\begin{array}{l}\text { Grays } \\
\text { Lake }\end{array}$ & Ririe & $\begin{array}{l}\text { Ririe } \\
\text { Upstream }\end{array}$ & $\begin{array}{l}\text { Grays } \\
\text { Lake }\end{array}$ \\
\hline NSE & 0.428 & 0.778 & 0.918 & 0.660 & 0.851 & 0.836 & 0.567 & 0.858 & 0.911 \\
\hline $\begin{array}{l}\text { Percent } \\
\text { Bias }\end{array}$ & -58.38 & -34.28 & -21.07 & -47.05 & -19.47 & -7.37 & -52.51 & -24.81 & -12.38 \\
\hline RMSE & 0.76 & 0.47 & 0.29 & 0.58 & 0.39 & 0.41 & 0.66 & 0.38 & 0.30 \\
\hline Date Peak & $\begin{array}{l}3 / 15 / 2 \\
0\end{array}$ & $3 / 16 / 20$ & $4 / 7 / 20$ & $3 / 22 / 20$ & $4 / 6 / 20$ & $4 / 24 / 20$ & $\begin{array}{l}3 / 16 / 2 \\
0\end{array}$ & $4 / 6 / 20$ & $\begin{array}{l}4 / 20 / 2 \\
0\end{array}$ \\
\hline $\begin{array}{l}\text { Observed } \\
\text { Peak Date }\end{array}$ & $\begin{array}{l}3 / 15 / 2 \\
0\end{array}$ & $4 / 5 / 20$ & $4 / 17 / 20$ & $3 / 15 / 20$ & $4 / 5 / 20$ & $4 / 17 / 20$ & $\begin{array}{l}3 / 15 / 2 \\
0\end{array}$ & $4 / 5 / 20$ & $\begin{array}{l}4 / 17 / 2 \\
0\end{array}$ \\
\hline Peak SWE & 4.19 & 7.29 & 9.49 & 4.65 & 8.11 & 10.71 & 4.51 & 7.69 & 10.45 \\
\hline $\begin{array}{l}\text { Observed } \\
\text { Peak SWE }\end{array}$ & 7.37 & 10.74 & 12.59 & 7.37 & 10.74 & 12.59 & 7.37 & 10.74 & 12.59 \\
\hline
\end{tabular}




\subsection{RTI parameter sensitivity}

A sensitivity analysis of the RTI parameters ATI coefficient and $N M F_{\text {max }}$ was completed to determine how the RTI parameterizations affect the heat deficit budget, peak SWE, and timing of peak SWE. The sensitivity analysis presented in this section was completed using the WY 2017 temperature and precipitation grids. The relative behavior of each parameter can be used to aid with understanding the implications of the different models' parameterizations.

\subsubsection{Peak SWE}

Using the default RTI model parameters, the ATI coefficient was varied between 0.1 and 0.9 using 0.1 intervals (Figure 23). The analysis indicated that the magnitude of peak SWE decreased with larger ATI coefficients. The magnitude of peak SWE values ranged from 1.45, 1.6, and 1.45, for Ririe, Ririe Upstream, and Grays Lake subbasin, respectively.

Figure 23. ATI parameter relationship between modeled peak SWE.

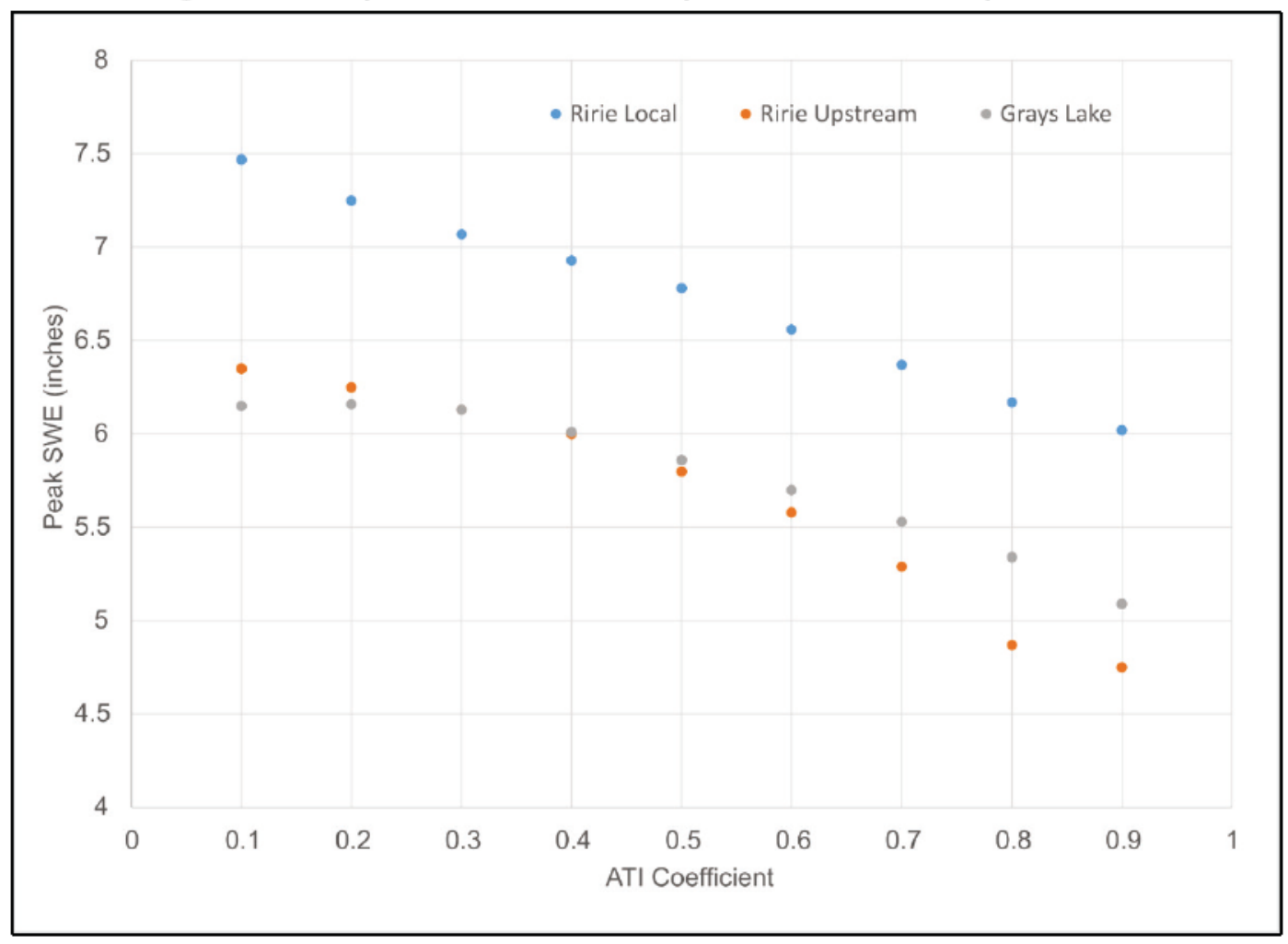


To evaluate the influence of $N M F_{\max }$ and ATI coefficient on SWE accumulation (Figure 24), we evaluated $N M F_{\max }$ values ranging from 0.001 to 0.051 at 0.002 intervals. In this analysis, the ATI coefficient was varied between three characteristic values (0.3, 0.5 , and 0.8$)$ selected to represent low, medium, and high parameterizations. There is a general trend where peak SWE increases with larger values of $N M F_{\text {max }}$, but there are certain parameter combinations in Ririe Upstream and Grays Lake where peak SWE remained constant. Lower values of the ATI coefficient resulted in larger values of peak SWE.

Figure 24. Relationship between maximum negative melt factor, ATI coefficient, and peak SWE.

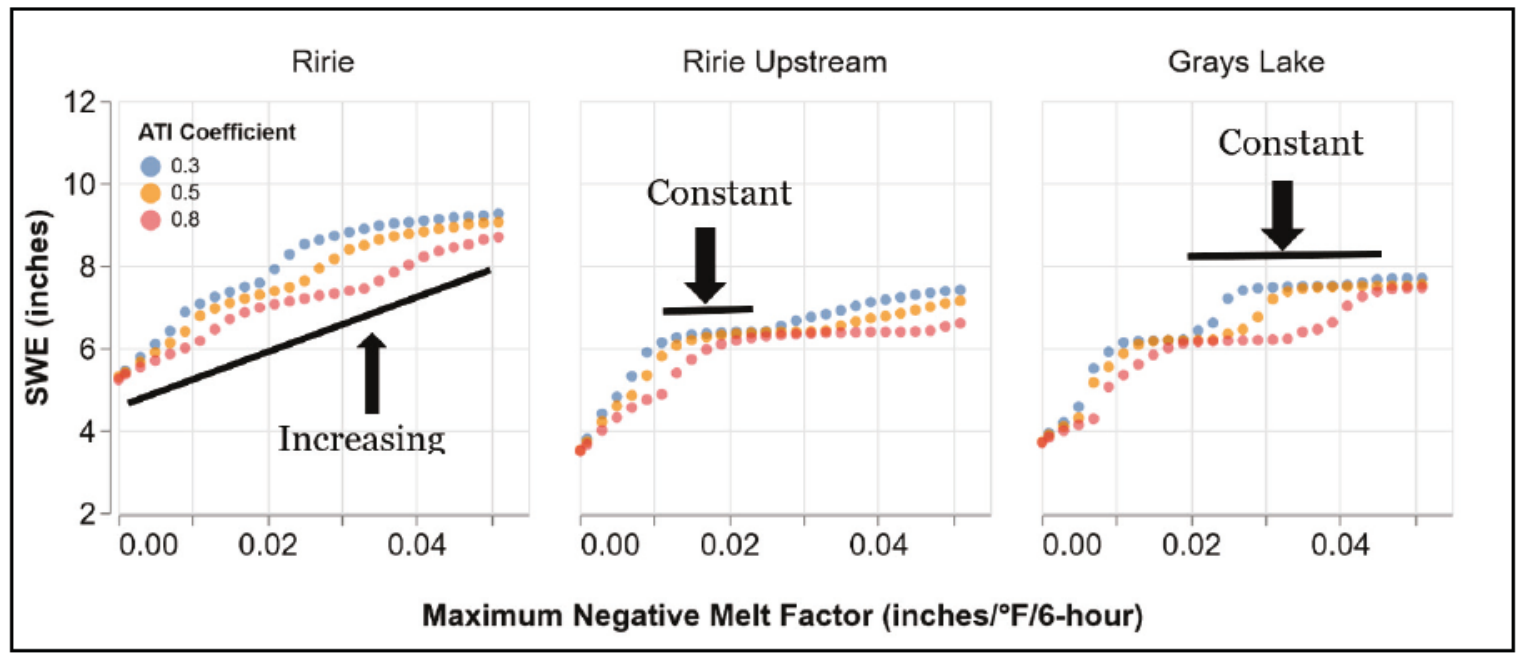

\subsubsection{Peak SWE timing}

Figure 25 shows how combinations between ATI coefficient and $N M F_{\text {max }}$ affect the timing of the simulated peak SWE. As $N M F_{\max }$ factor increases, the timing of peak SWE is shifted later in the WY. The Ririe subbasin generally had two results for the timing of peak SWE, where the timing shifts were delayed with increasing ATI coefficients. The Ririe Upstream subbasin had three, discrete results for the timing of peak SWE. Grays Lake had a less stepwise solution, where the timing of SWE gradually increased with maximum negative melt factor. The gradual delay of peak SWE timing in Grays Lake is likely due to the plateau of peak SWE shown in Figure 25. 
Figure 25. Relationship between maximum negative melt factor, ATI coefficient, and peak SWE timing.

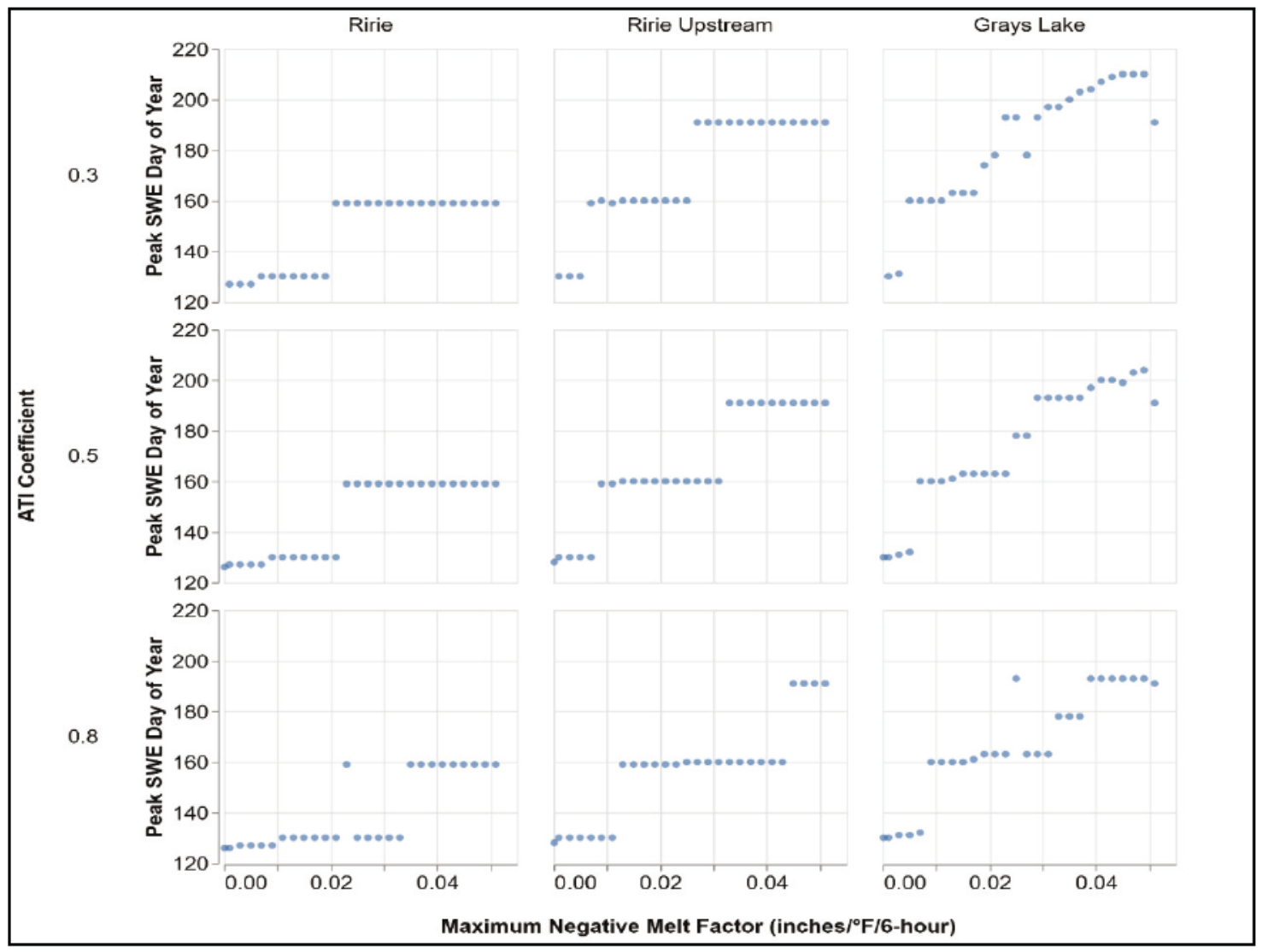

\subsubsection{Heat deficit}

Figure 26 shows how the heat deficit budget will vary with different combinations of $N M F_{\text {max }}$ and ATI coefficient. Lower values of $N M F_{\text {max }}$ resulted in multiple heat deficit cycles throughout the winter in Ririe Local. Similar trends exist for Ririe Upstream and Gray Lake, but the heat deficit cycles do not always reach zero. The magnitude of the heat deficit increased with $N M F_{\max }$ and decreasing values of the ATI coefficient. 
Figure 26. Influence of maximum negative melt factor and ATI coefficient on the heat deficit budget.

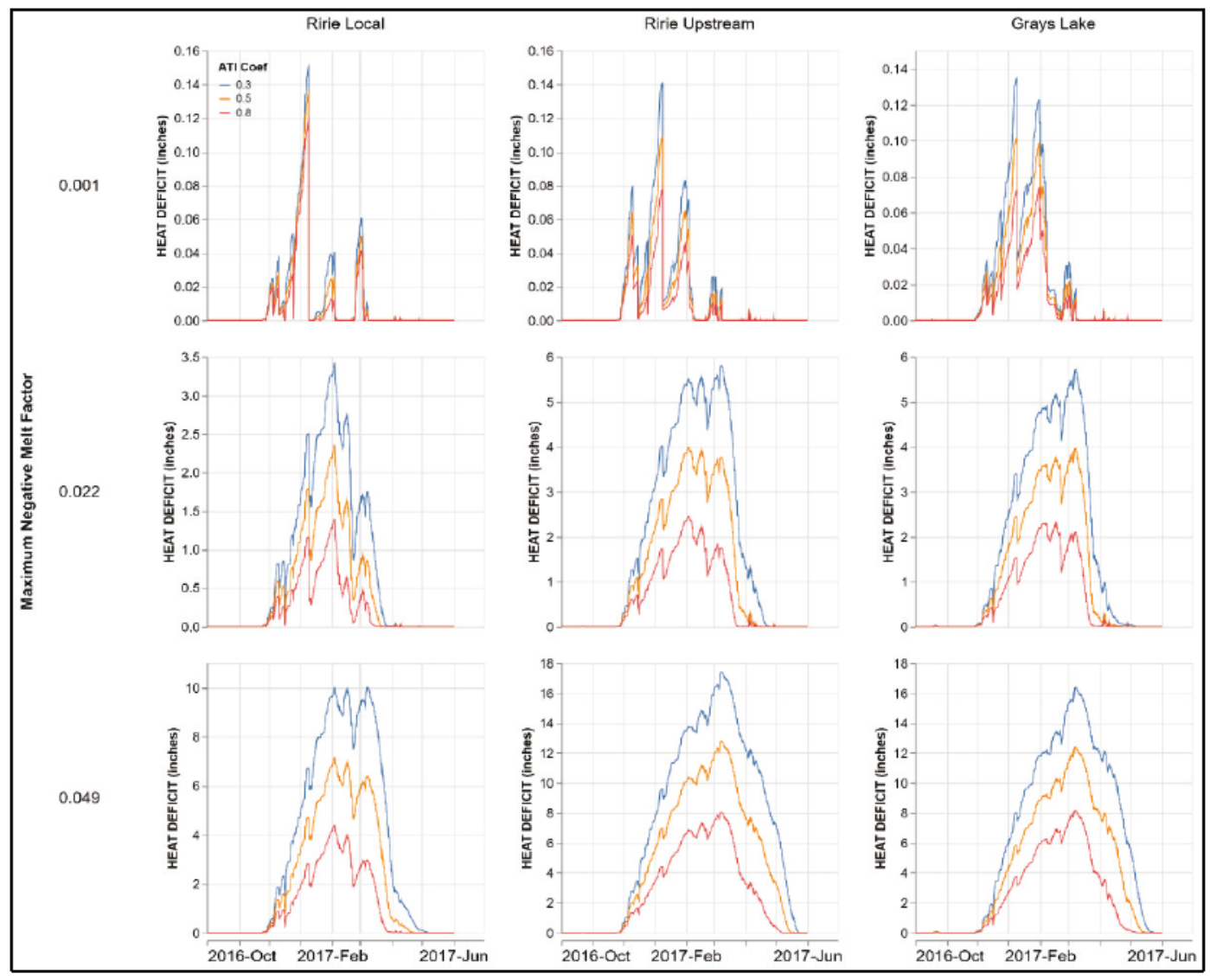




\section{Discussion}

As indicated in the approach section, this discussion is a summary of items that might help guide future work for the RTI model development.

\subsection{RTI model parameters}

The sensitivity analysis provided above indicates that the model is highly sensitive to specific parameter combinations. These results are further demonstrated when each of the calibration sets was used to simulate WYs 2018-2020. A trend seen across the calibration and simulation years is that there is minimal to no melt occurring during the accumulation periods. The SWE time series had a stair-like pattern where accumulation would be followed by a period of constant SWE. A good place to start an investigation into this pattern is to review the heat deficit budget algorithm for errors. Potential runoff can only occur when there is more melt than heat deficit. Based on the trends identified in Figure 25, large values of non-negative melt factor result in large magnitude heat deficits. An implication of large magnitude heat deficits is runoff will be delayed until the heat deficit is satisfied.

Another area to investigate is the current formulation of the negative melt factor calculations. Approximating the seasonal variation of melt factors with ratios of downwelling shortwave radiation is problematic in Willow Creek because peak SWE will occur well before the summer equinox. The current model will not accept non-negative melt factors greater than 0.052 . Subbasins with earlier peak SWE would require larger negative melt factors to force the model to overcome a heat deficit budget when the ratio of daily maximum to annual maximum shortwave solar radiation is small.

\subsection{Surface runoff}

All runoff comparisons between the RTI and TI models were completed using the US Geological Survey (USGS) gage Willow Creek Below Tex (USGS Gauge 13057940). This gage is located at the outlet of Ririe Upstream and provides the best comparison because the RTI models were calibrated to obtain maximum performance in the Ririe Upstream subbasin. For each calibration year, the loss and baseflow parameters were adjusted to obtain maximum performance for the RTI model. The 
corresponding TI model was also simulated using the loss and baseflow parameters calibrated in the RTI model.

Figure 27 shows the result of the runoff simulation using the calibration datasets for WY 2016. While both the RTI and TI models produce reasonable streamflow results, the RTI model has overall better results for NSE, bias, and RMSE values (Table 15). In contrast, the results for WY 2017 shows the TI simulation (Figure 28) performed much better compared to the observed streamflow. During the basin model calibration for WY 2017, parameters were varied to obtain an oscillating hydrograph similar to the observed record. Ultimately, there was no set of parameters that produced an oscillating behavior. It was a surprising finding to see that the TI model captured some of the oscillating behavior when land surface parameters in HEC-HMS (baseflow and loss) were originally calibrated in the RTI model.

Figure 27. Willow Creek below Tex (13057940) streamflow for the WY 2016.

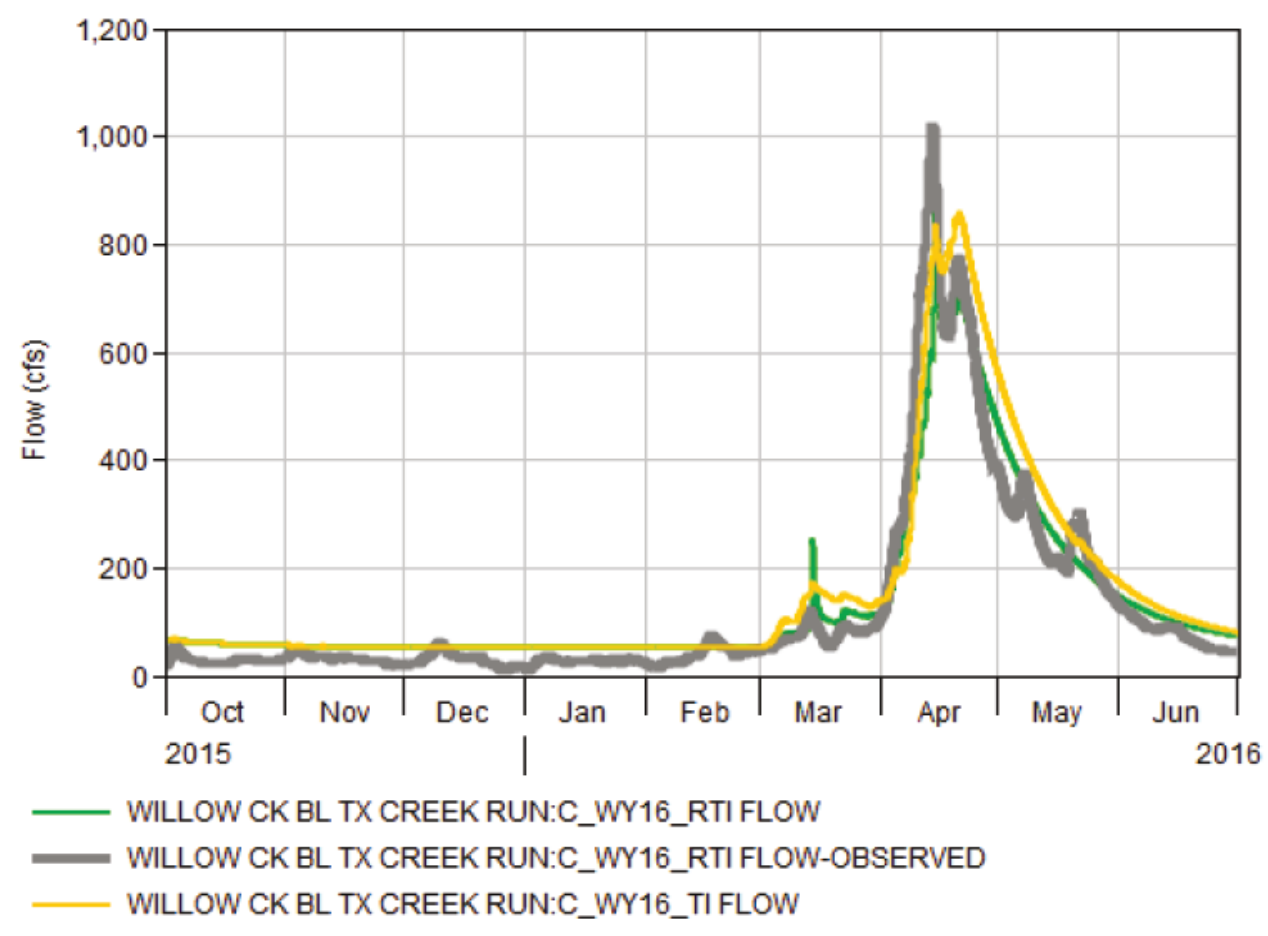


Figure 28. Willow Creek below Tex streamflow for the WY 2017.

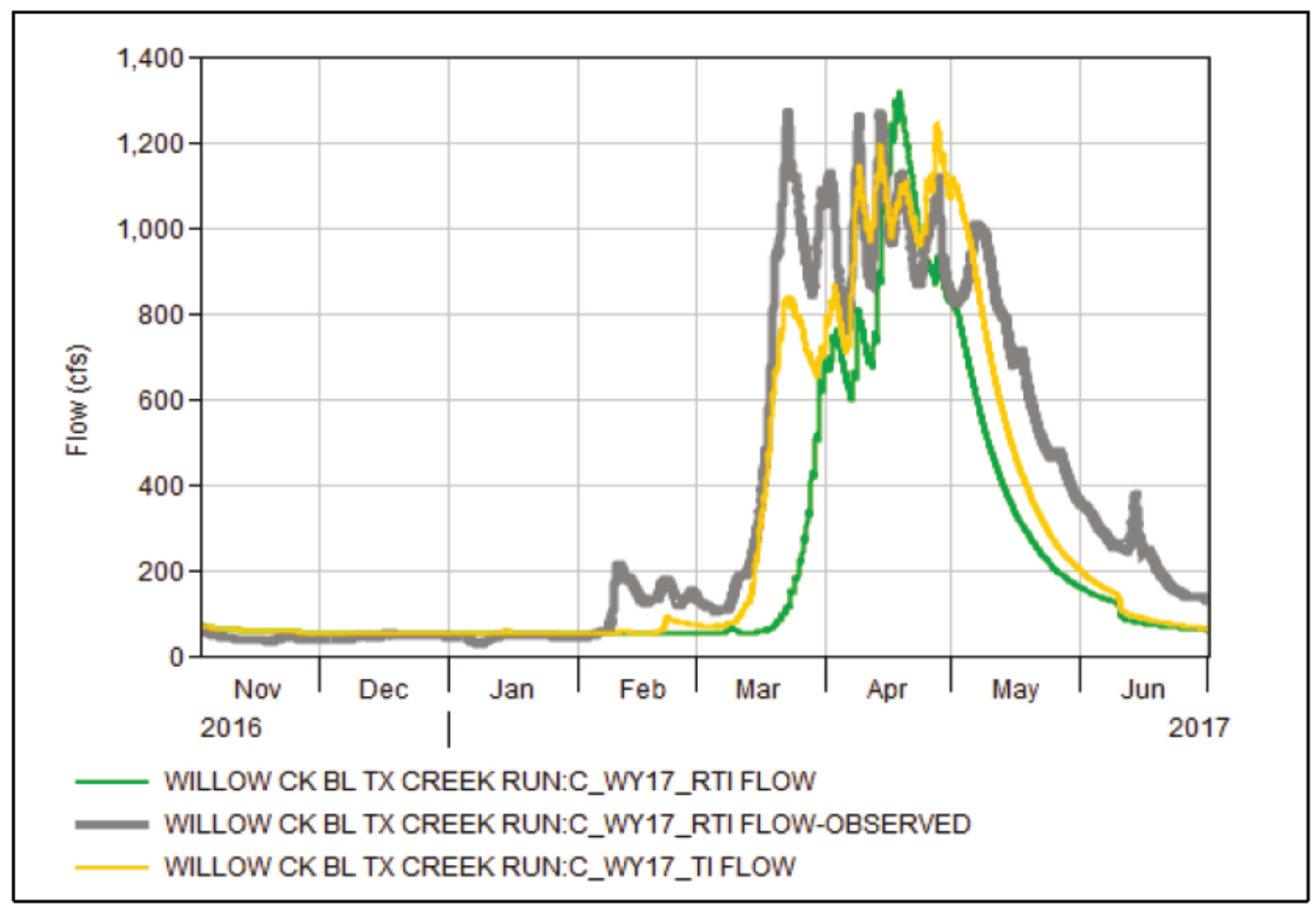

Table 15. RTI and TI stream flow statistics for WYs 2016 and 2017.

\begin{tabular}{|l|l|l|l|l|l|l|}
\hline \multicolumn{2}{|c|}{} & \multicolumn{2}{l|}{ Willow Creek below Tex Creek } & \multicolumn{2}{l|}{} \\
\hline WY & Model & NSE & Percent Bias & RMSE & $\begin{array}{l}\text { Volume } \\
\text { (inches) }\end{array}$ & $\begin{array}{l}\text { Observed } \\
\text { Volume } \\
\text { (inches) }\end{array}$ \\
\hline 2016 & RTI & 0.907 & 10.05 & 0.3 & 2.43 & 2.21 \\
\hline & TI & 0.653 & 25.07 & 0.6 & 2.77 & \\
\hline 2017 & RTI & 0.599 & -35.85 & 0.6 & 3.46 & 5.39 \\
\hline & TI & 0.925 & -2.48 & 0.3 & 5.36 & \\
\hline
\end{tabular}




\section{Conclusion}

The TI model for Willow Creek performed reasonably well in both the calibration and validation years. These results could be used by USACE water managers to make operational decisions for Ririe Dam. However, the results of the RTI calibration and validation simulations leave us with additional questions related to how best to parameterize this snow model. The sensitivity analysis indicates that the choice of calibration years will have a substantial impact on the parameters and thus the streamflow results. Based on the analysis completed in this study, we think further refinement and verification of the RTI model calculations are required before an objective comparison with the temperature index model can be completed. The following list of tasks should be completed before additional comparisons are made with SWE and streamflow using the RTI model.

- A full review of the RTI code should be completed to document all assumptions made in the original implementation.

- A thorough review of the parameter assumptions and any other hardcoded values used in the original implementation should be conducted.

- Additional sensitivity analysis should be performed along with tracebacks through the foundational equations. This will allow us to understand and document how variables are updated at each time-step.

- An additional review should be made of how the RTI model is percolating water through the snowpack. This is probably one of the most challenging issues since water is released across multiple time-steps.

- Develop documentation of each HEC-HMS input. This includes acceptable ranges, physical meaning, and source references.

- Add radiative temperature and heat deficit components to output DSS variables.

- Standardize nomenclature between the TI and RTI models (e.g., ATI and ATI-Cold).

- Implement subbasin-level parameterizations in the RTI model. 


\section{References}

Anderson, Eric A. 2006. Snow Accumulation and Ablation Model - SNOW 17. Silver Spring, MD: US National Weather Service. https://www.nws.noaa.gov/oh/hrl/nwsrfs/users manual/part2/ pdf/22snow17.pdf.

Brauer, Thomas, and Nick Van. 2020. HydrologicEngineeringCenter/Vortex: Vo.10.4 (version vo.10.4). Zenodo. https://doi.org/10.5281/ZENOD0.4035368.

Broxton, Patrick. 2019. "Daily 4 Km Gridded SWE and Snow Depth from Assimilated InSitu and Modeled Data over the Conterminous US, Version 1." NASA National Snow and Ice Data Center DAAC. https://doi.org/10.5067/0GGPB220EX6A.

Broxton, Patrick. 2020. "Daily 4 Km Gridded SWE and Snow Depth from Assimilated InSitu and Modeled Data over the Conterminous US." University of Arizona, Climate Dynamics and Hydrometeorology Center. Accessed September 1, 2020. https://climate.arizona.edu/data/UA SWE/DailyData/.

Daly, C., M. Halbleib, J. I. Smith, W. P. Gibson, M. K. Doggett, G. H. Taylor, J. Curtis, and P. A. Pasteris. 2008. "Physiographically-Sensitive Mapping of Temperature and Precipitation across the Conterminous United States." International Journal of Climatology 28: 2031-2064.

Debele, Bekele, Raghavan Srinivasan, and A. K. Gosain. 2009. "Comparison of ProcessBased and Temperature-Index Snowmelt Modeling in SWAT." Water Resources Management 24(6): 1065-88. https://doi.org/10.1007/s11269-009-9486-2.

De Pondeca, Manuel S. F. V., Geoffrey S. Manikin, Geoff DiMego, Stanley G. Benjamin, David F. Parrish, R. James Purser, Wan-Shu Wu, et al. 2011. "The Real-Time Mesoscale Analysis at NOAA's National Centers for Environmental Prediction: Current Status and Development." Weather and Forecasting 26(5): 593-612. https://doi.org/10.1175/waf-d-10-05037.1.

Dettinger, Michael D. 2013. "Atmospheric Rivers as Drought Busters on the US West Coast." Journal of Hydrometeorology 14(6): 1721-32. https://doi.org/10.1175/ihmd-13-02.1.

Follum, Michael L., Charles W. Downer, Jeffrey D. Niemann, Spencer M. Roylance, and Carrie M. Vuyovich. 2015. "A Radiation-Derived Temperature-Index Snow Routine for the GSSHA Hydrologic Model.” Journal of Hydrology 529(October): 723-36. https://doi.org/10.1016/i.jhydrol.2015.08.044.

GDAL (Geospatial Data Abstraction Library). 2021. Geospatial Data Abstraction Software Library. https://gdal.org.

Gesch, Dean B., Gayla A. Evans, Michael J. Oimoen, and Samantha Arundel. 2018. "The National Elevation Dataset." Digital Elevation Model Technologies and Applications. Edited by David Maune and Amar Nayegandhi, 3rd ed. Bethesda: American Society for Photogrammetry and Remote Sensing. http://pubs.er.usgs.gov/publication/70201572. 
Giovando, Jeremy, Chandler Engel, Steven Daly, Michael Warner, Daniel Hamill, Evan Heisman. 2020. Wintertime Snow and Precipitation Conditions in the Willow Creek Watershed above Ririe Dam, Idaho. ERDC/CRREL TR-21-6. Hanover, NH: US Army Engineer Research and Development Center. http://dx.doi.org/10.21079/11681/40479

Hildebrand, C. E., and T. H. Pagenhart. 1955. "Lysimeter Studies of Snowmelt." Res. Note 25, Snow Investigations. Portland, OR: Northern Pacific Div. Corps of Engr., US Army.

Hock, Regine. 2003. "Temperature Index Melt Modelling in Mountain Areas." Journal of Hydrology 282(1-4): 104-15. https://doi.org/10.1016/s0022-1694(03)00257-9.

Melloh, Rae A. 1999. A Synopsis and Comparison of Selected Snowmelt Algorithms." CRREL Report 99-8. Vicksburg, MS: US Army Engineer Research and Development Center. https://hdl.handle.net/11681/9248

Mesonet, Iowa Environmental. 2020. "Iowa State University." Department of Agronomy. Accessed September 13, 2020. https://mtarchive.geol.iastate.edu/.

Ohmura, Atsumu. 2001. "Physical Basis for the Temperature-Based Melt-Index Method." Journal of Applied Meteorology 4o(4): 753-61. https://doi.org/10.1175/15200450(2001)040<0753:pbfttb>2.0.c0;2.

PRISM. 2020. Oregon State University. Accessed 26 May 2021. http://prism.oregonstate.edu.

Thomas, Cecil Albert, and Robert D. Lamke. 1962. Floods of February 1962 in Southern Idaho and Northeastern Nevada. Circular. US Geological Survey.

https://doi.org/10.3133/cir467.

USACE (US Army Corps of Engineers). 1966. Design Memorandum No. 1, Ririe Dam and Reservoir, Willow Creek, Idaho, Hydrology. US Army Engineer District, Walla Walla, Corps of Engineers.

USACE. 1987. SSARR Model, Streamflow Synthesis and Reservoir Regulation. User Manual. (Reprinted 1991). US Army Corps of Engineers, North Pacific Division.

USACE. 2017. Snowmelt Model Development for the Corps Water Management Systems. Report 3.1.38. US Army Corps of Engineers, Modelling, Mapping, and Consequences. Washington, DC.

Zeng, Xubin, Patrick Broxton, and Nicholas Dawson. 2018. "Snowpack Change From 1982 to 2016 Over Conterminous United States." Geophysical Research Letters 45(23). https://doi.org/10.1029/2018gl079621.

Zhang, Jian, Kenneth Howard, Carrie Langston, Brian Kaney, Youcun Qi, Lin Tang, Heather Grams, et al. 2016. "Multi-Radar Multi-Sensor (MRMS) Quantitative Precipitation Estimation: Initial Operating Capabilities." Bulletin of the American Meteorological Society 97(4): 621-38. https://doi.org/10.1175/bams-d-14$\underline{00174.1}$. 


\section{Acronyms and Abbreviations}

\begin{tabular}{ll} 
DEM & digital elevation model \\
DSS & Data Storage System \\
GIS & geographic information system \\
HADS & Hydrometeorological Automated Data System \\
HEC-HMS & Hydrologic Engineering Center, Hydrological Modeling System \\
HMS & Hydrological Modeling System \\
MRMS & Multi Radar Multi-Sensor \\
NLCD & National Landcover Classification Database \\
NOAA & National Oceanic and Atmospheric Administration \\
NSE & Nash-Sutcliffe efficiency \\
PRISM & Parameter-elevation Regressions on Independence slopes model \\
QPE & quantitative precipitation estimate \\
RMSE & root mean square error \\
RTI & radiative temperature index \\
RTMA & Real-Time Mesoscale Analysis \\
SNOTEL & Snow Telemetry \\
SWE & Snow Water Equivalent \\
TI & temperature index \\
UA & University of Arizona \\
USACE & US Army Corps of Engineers \\
USGS & US Geological Survey \\
WY & water year \\
\hline
\end{tabular}




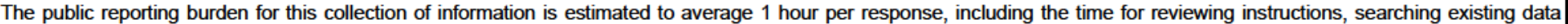

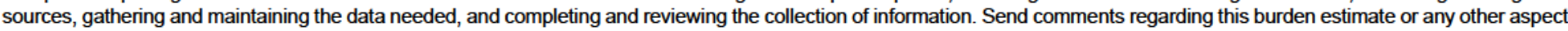

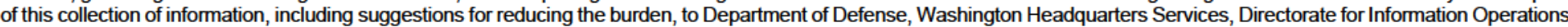

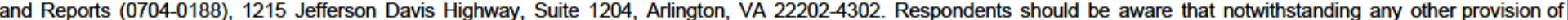
law, no person shall be subject to any penalty for failing to comply with a collection of information if it does not display a currently valid OMB control number. PLEASE DO NOT RETURN YOUR FORM TO THE ABOVE ADDRESS.

\begin{tabular}{l|l|l}
\hline $\begin{array}{l}\text { 1. REPORT DATE } \\
\text { July } 2021 .\end{array}$ & $\begin{array}{l}\text { 2. REPORT TYPE } \\
\text { Final Report }\end{array}$ & 3. DATES COVERED (From - To)
\end{tabular}

\section{TITLE AND SUBTITLE}

Final Report

Application of a Radiation-Derived Temperature Index Model to the Willow Creek Watershed in Idaho, USA

5a. CONTRACT NUMBER

5b. GRANT NUMBER

5c. PROGRAM ELEMENT NUMBER

6. AUTHOR(S)

Daniel Hamill, Jeremy Giovando, Chandler Engel, Travis Dahl, and Mike Bartles

5d. PROJECT NUMBER

Project No. 484151

5e. TASK NUMBER

5f. WORK UNIT NUMBER

7. PERFORMING ORGANIZATION NAME(S) AND ADDRESS(ES)

Cold Regions Research and Engineering

Laboratory

US Army Engineer Research and

Development Center

72 Lyme Road

Hanover, NH 03755

9. SPONSORING/MONITORING AGENCY NAME(S) AND ADDRESS(ES)

Flood and Coastal System (FCS) Research and Development Program

3909 Halls Ferry Road

Vicksburg, MS 39180

Coastal and Hydraulics Laboratory

US Army Research and Development Center 3909 Halls Ferry Road

Vicksburg, MS 39180-6199
8. PERFORMING ORGANIZATION REPORT NUMBER

ERDC TR-21-11

\section{DISTRIBUTION/AVAILABILITY STATEMENT}

Approved for public release; distribution is unlimited.

\section{SUPPLEMENTARY NOTES}

Funding Account Code U4368971, AMSCO Code 31398

\section{ABSTRACT}

The ability to simulate snow accumulation and melting processes is fundamental to developing real-time hydrological models in watersheds with a snowmelt-dominated flow regime. A primary source of uncertainty with this model development approach is the subjectivity related to which historical periods to use and how to combine parameters from multiple calibration events. The Hydrologic Engineering Center, Hydrological Modeling System, has recently implemented a hybrid temperature index (TI) snow module that has not been extensively tested. This study evaluates a radiatative temperature index (RTI) model's performance relative to the traditional air TI model. The TI model for Willow Creek performed reasonably well in both the calibration and validation years. The results of the RTI calibration and validation simulations resulted in additional questions related to how best to parameterize this snow model. An RTI parameter sensitivity analysis indicates that the choice of calibration years will have a substantial impact on the parameters and thus the streamflow results. Based on the analysis completed in this study, further refinement and verification of the RTI model calculations are required before an objective comparison with the TI model can be completed.

\section{SUBJECT TERMS}

Hydrologic models, Ririe Dam (Idaho), Runoff, Snow

16. SECURITY CLASSIFICATION OF:

\begin{tabular}{|l|l|l|}
\hline a. REPORT & b. ABSTRACT & c. THIS PAGE \\
Unclassified & Unclassified & Unclassified \\
\hline
\end{tabular}
17. LIMITATION OF
ABSTRACT

SAR
18. NUMBER OF PAGES

64 19a. NAME OF RESPONSIBLE PERSON Daniel Hamill

19b. TELEPHONE NUMBER (Include area code) 603-646-4240 